\title{
SOUDNÍ OCHRANA ČLENA SPOLEČENSTVÍ VLASTNÍKŮ JEDNOTEK
}

\author{
TOMÁŠ DVOŘÁK
}

\begin{abstract}
The Judicial Protection of a Member of the Community of Unit Owners
This scientific study deals with the issue of judicial protection of a member of the community of unit owners after the amendment of Act No. 89/2012 Sb., The Civil Code, as amended by Act No. 163/2020 Sb. (with effect from 1 July 2020). Judicial protection of a member of a community of unit owners covers three basic issues. The first is the issue of judicial protection against invalid and void resolutions of the Assembly. The second is the issue of a substantive review of valid assembly resolutions by the court. Finally, the issue of replacing pending resolutions of the assembly by court decisions. The study deals with both substantive and procedural issues. The author formulates the conclusion that the legal regulation is very complicated from a theoretical point of view and from a practical point of view will cause considerable difficulties in application.
\end{abstract}

Keywords: member of the community of unit owners; judicial protection; assembly resolution

Klíčová slova: člen společenství vlastníků jednotek; soudní ochrana; usnesení shromáždění

DOI: $10.14712 / 23366478.2021 .22$

\section{1. ÚVODNÍ VÝKLADY}

Členové společenství vlastníků jednotek (dále jen „společenství“) mají možnost dovolat se relevantní soudní ochrany proti těm protiprávním rozhodnutím, jež se dotýkají práv a povinností člena společenství, se kterými jsou - vzhledem k povaze společenství jakožto právnické osoby určené výhradně ke správě společných částí nemovitosti ${ }^{1}$ (dále jen ,společné části“) - neoddělitelně spojena i práva a povinnosti vlastníka jednotky. Člen společenství přitom musí mít účinnou obranu před př́padnou nečinností, svévolí nebo nezákonnými postupy společenství, resp. jeho orgánů.

1 Správou společných částí nemovitosti se v této studii rozumí správa podle § 1189 ObčZ. Zákonný terminus technicus správa domu a pozemku se zde nepouživá pro jeho zjevnou chybnost, nebot' nejde o komplexní správu celé nemovitosti (= celého domu a pozemku), nýbrž o zvláštní druh správy toliko určitých (= společných) částí nemovitosti v bytovém spoluvlastnictví. 
Zásadní skutečností v daném kontextu je, že nedávná novelizace občanského zákoníku provedená zákonem č. 163/2020 Sb. (s účinností od 1. 7. 2020) právní úpravu soudní ochrany člena společenství dosti zásadním způsobem změnila.

Za existence zákona č. 72/1994 Sb., kterým se upravují některé spoluvlastnické vztahy $\mathrm{k}$ budovám a některé vlastnické vztahy $\mathrm{k}$ bytům a nebytovým prostorům a doplňují některé zákony (zákon o vlastnictví bytů), ve znění po novele provedené zákonem č. 103/2000 Sb. (s účinností od 1. 7. 2000) až do jeho zrušení (do 31. 12. 2013), nebylo zřejmé, zda se člen společenství může žalobou podanou podle $\S 11$ odst. 3 věty třetí zákona č. 72/1994 Sb. domáhat toliko vyslovení neplatnosti usnesení shromáždění nebo zda je možný - obdobně jako v právní úpravě podílového spoluvlastnictví - také věcný zásah soudu do vnitřních poměrů společenství i tam, kde přijaté usnesení shromáždění je platné. Stejný problém pak představovala dikce $\S 1209$ odst. 1 ObčZ ve znění účinném do 30. 6. 2020.

Soudní judikatura - patrně pod vlivem kogentní právní úpravy neplatnosti usnesení valné hromady kapitálové obchodní společnosti, resp. neplatnosti usnesení členské schůze družstva - dospěla k závěru, že nic jiného než soudní přezkum neplatnosti usnesení shromáždění není možný (civ. R 58/2012 aj.); toto stanovisko přitom bylo zachováno i po nabytí účinnosti nového občanského zákoníku. ${ }^{2}$

Právní věda nebyla ovšem stejného názoru. J. Holejšovský již za účinnosti zákona č. 72/1994 Sb. dovozoval př́ípustnost věcného přezkumu platného usnesení shromáždění soudem; ${ }^{3}$ stejný závěr pak formuloval i na podkladě $\$ 1209$ odst. 1 ObčZ ve znění účinném do 30. 6. 2020. ${ }^{4} \mathrm{~V}$ zásadě stejný názor formulovala i E. Kabelková, a to opakovaně. ${ }^{5}$ Nejednoznačný pak byl názor Z. Čápa, jenž se k této otázce př́mo nevyjádřil, z celkového kontextu jeho komentáře se však bylo možno domnívat, že taktéž dovozuje př́ípustnost věcného přezkumu platného usnesení shromáždění soudem. ${ }^{6}$

Praktické obtíže, které z tohoto judikatorního výkladu vznikaly (jakož i zjevná neústupnost soudů, jež zjevně nehodlaly svůj problematický výklad zákona změnit), nakonec přiměly zákonodárce $\mathrm{k}$ radikálnímu kroku v podobě př́ímé novelizace $§ 1209$ odst. 1 ObčZ. Zákonodárce přitom přijal normativní řešení přesně obrácené, než jaké dovodily soudy; došlo k uzákonění možnosti věcného přezkumu platného usnesení shromáždění soudem. ${ }^{7}$ Přijatá úprava je přitom i po novelizaci výkladově značně složitá a rozhodně nikoliv bezproblémová.

2 Usnesení Nejvyššího soudu ze dne 15. 3. 2017, sp. zn. 26 Cdo 4567/2016, ASPI JUD348677CZ.

3 HOLEJŠOVSKÝ, J. in: FIALA, J. - NOVOTNY, M. - HORÁK, T. - OEHM, J. - HOLEJŠOVSKÝ, J. Zákon o vlastnictví bytù: komentáŕ. 4. vyd. Praha: C. H. Beck, 2011, s. 177.

4 HOLEJŠOVSKÝ, J. in: SPÁČIL, J. a kol. Občanský zákonik. III, Věcná práva (§ 976-1474): komentáŕ. Praha: C. H. Beck, 2013, s. 821.

5 KABELKOVÁ, E. in: KABELKOVÁ, E. - SCHÖDELBAUEROVÁ, P. Bytové spoluvlastnictví v novém občanském zákoniku: komentár. Praha: C. H. Beck, 2013, s. 276; KABELKOVÁ, E. in: PETROV, J. VÝTISK, M. - BERAN, V. a kol. Občanský zákoník: komentář. Praha: C. H. Beck, 2017, s. 1222.

6 ČÁP, Z. in: ŠVESTKA, J. - DVOŘÁK, J. - FIALA, J. - VYCHOPEŇ, M. - WINTEROVÁ, A. - ČÁP, Z. - THÖNDEL, A. a kol. Občanský zákonik: komentár. Svazek III, (§ 976-1474). Praha: Wolters Kluwer, 2014, s. 622-624.

7 Poslanecká sněmovna Parlamentu ČR, VIII. volební období (od 2017). Parlamentní tisk č. 411/0, důvodová zpráva, zvláštní část, čl. I., body 47 a 48 . 


\section{OTÁZKA (NE)PŘIIPUSTNOSTI SOUDNÍHO PŘEZKUMU ROZHODNUTÍ VOLENÝCH ORGÁNU゚ SPOLEČENSTVÍ}

Dikce $§ 258$ a násl. ObčZ a taktéž dikce $§ 1209$ ObčZ8 vyvolává otázku zásadní povahy, totiž zda jsou citované předpisy aplikovatelné výhradně na usnesení shromáždění jakožto nejvyššího orgánu společenství (restriktivní výklad) nebo na rozhodnutí všech orgánů společenství (extenzivní výklad).

Z dikce právní úpravy spolku je zjevné, že se zákonné předpisy o vadách rozhodnutí orgánu spolku a soudní ochraně členů spolku použijí na rozhodnutí veškerých orgánů spolku. Naproti tomu právní předpisy obchodního práva připouští soudní ochranu společníků kapitálových obchodních společností a členů družstev toliko vůči vadám rozhodnutí nejvyšších orgánů kapitálových obchodních společností a družstev. ${ }^{9}$

Nelze souhlasit se stanoviskem zaujatým soudní praxí, ${ }^{10}$ a také částí právní vědy, ${ }^{11}, 12$ totiž že v poměrech společenství je třeba zaujmout výklad extenzivní a poskytnout soudní ochranu členům společenství proti vadám rozhodnutí všech orgánů společenství. Naopak je namístě výklad restriktivní; důvody jsou následující.

Pro primo, předmětný judikát byl vydán podle právní úpravy účinné do 30. 6. 2020, novela provedená zákonem č. 163/2020 Sb. však stav normativní úpravy nemálo změnila, tudíž právní názor zde publikovaný je již překonán.

Pro secundo, pokud by se dovodila aplikace $\S 1209$ odst. 1 a 2 ObčZ i na volené orgány, pak by zde vznikla neřešitelná situace; člen společenství z titulu svého členství ve společenství nikdy není členem voleného orgánu, tudíž by nemohl splnit zákonnou podmínku přehlasování ve voleném orgánu a nikdy by tak nemohl být aktivně legitimován. Výsledkem toho by tedy byl stav, kdy by nikdo neměl aktivní legitimaci domáhat se soudního přezkumu rozhodnutí voleného orgánu podle § 1209 odst. 1 a 2 ObčZ, což je ovšem zcela absurdní a nepřijatelný výsledek.

Pro tertio, z dikce $\S 1209$ odst. 3 ObčZ zřetelně a výslovně plyne, že soud může nahradit chybějící usnesení toliko shromáždění, nikoliv voleného orgánu. Jeví se tudíž logickým závěr, že chtěl-li zákonodárce umožnit soudní nahrazení chybějícího usnesení toliko shromáždění, pak chtěl též umožnit soudní přezkum neplatnosti usnesení a nahrazení vadného usnesení taktéž toliko shromáždění.

Pro quarto, ve spolku je nezbytné umožnit soudní přezkum rozhodnutí všech orgánů, protože zákon připouští, aby o podstatných otázkách spolku (např. změna stanov aj.)

8 Ustanovení $§ 1209$ ObčZ ve znění účinném od 1. 7. 2020 dopadá i na soudní ochranu vlastníka jednotky ve věcech (a) změny prohlášení vlastníka (§ 1169 odst. 3 ObčZ), (b) náležejících do působnosti schůze vlastníků jednotek, jestliže společenství nevzniklo (§ 1191 odst. 2 ObčZ), a (c) založení společenství (§ 1200 odst. 1 ObčZ). O těchto speciálních úpravách se zde však nepojednává.

9 Výše uvedené ovšem neplatí bez výjimky; na půdě akciové společnosti je možný soudní přezkum platnosti rozhodnutí volených orgánů $\mathrm{v}$ těch př́padech, kdy na ně stanovy $\mathrm{v}$ zákonem vymezených př́padech přenášejí část působnosti valné hromady.

${ }^{10}$ Usnesení Nejvyššího soudu ze dne 10. 3. 2020, sp. zn. 27 Cdo 4639/2018, ASPI JUD446079CZ.

11 ČÁP, Z. in: ŠVESTKA - DVOŘÁK - FIALA - VYCHOPEŇ - WINTEROVÁ - ČÁP - THÖNDEL, c. d., s. 624. Třeba ovšem dodat, že tento zásadní názor citovaný autor nijak nezdůvodňuje.

12 Nejasné je stanovisko J. Holejšovského (in: SPÁČIL, $c$. d., s. 820), jenž se sice na straně jedné k tomuto výkladu přihlašuje, avšak se zjevnými pochybnostmi, a především v dalším textu citovaného komentáře k § 1209 odst. 1 ObčZ ve znění účinném do 30. 6. 2020 již hovoří výhradně o usnesení shromáždění. 
rozhodoval nejen nejvyšší orgán, ale i orgány volené, což ve společenství možné není, tudíž není potřebný soudní přezkum rozhodnutí volených orgánů společenství.

Pro quinto, v 1221 odst. 1 ObčZ je odkazováno toliko na přiměřenou (nikoliv obdobnou) aplikaci § 258 a násl. ObčZ na společenství. Legislativní termín „přiměřeně“ je nutno chápat jako interpretační pravidlo, jehož obsahem je takový postup při použití právního předpisu, při kterém se na nově upravené právní vztahy aplikují jen některé odpovídající části dosavadní právní úpravy, jež má být přiměřeně použita. ${ }^{13}$ Vzhledem $\mathrm{k}$ tomu nelze přistoupit $\mathrm{k}$ doslovné aplikaci $\S 258$ a násl. ObčZ na veškeré orgány společenství.

Pro sixto, cit. rozhodnutí14 nedává spolehlivou odpověd’ na položenou otázku. Jak totiž plyne z dikce rozhodnutí, jde o rozhodnutí v rejstř́íkovém řízení, nikoliv o rozhodnutí podle $\$ 1209$ ObčZ nebo podle $\S 258$ a násl. ObčZ. Soud zde toliko posuzoval platnost rozhodnutí výboru společenství, ovšem toliko jako otázku předběžnou. Meritorně otázka soudního přezkumu rozhodnutí volených orgánů společenství zkoumána dosud nebyla.

Pro výklad extenzivní stojí jen dva argumenty.

Prvý z nich je obsažen v odůvodnění cit. judikátu, ${ }^{15}$ jež však jen lapidárně konstatuje, že podle $\S 1221$ ObčZ lze v řízení podle $\S 258$ a násl. ObčZ přezkoumat neplatnost rozhodnutí i jiných orgánů společenství než toliko shromáždění. Druhý argument pak představuje výše cit. důvodová zpráva k návrhu zákona č. 163/2020 Sb., v níž se paušálně hovoří o neplatnosti rozhodnutí orgánu společenství. Zde ovšem existují dva protiargumenty; jednak je otázkou, zda si zákonodárce vůbec uvědomoval rozdíl mezi obecným pojmem orgánu společenství a konkrétním pojmem shromáždění jakožto jednoho z orgánů společenství, jednak nelze přehlížet klasické pravidlo, že ,,není rozhodujicí, co zákonodárce do zákona dáti chtěl, nýbrž jen to, co do něj skutečnè dal “. Úmysl zákonodárce umožnit věcný přezkum platných usnesení shromáždění je zjevný a nepochybný, ovšem úmysl zákonodárce umožnit soudní přezkum všech rozhodnutí orgánů společenství v zákonu expressis verbis vyjádřen není.

Logický závěr je tedy ten, že jak $§ 1209$ ObčZ, tak i § 258 a násl. ObčZ dopadají výhradně na usnesení shromáždění; jakýkoliv soudní přezkum rozhodnutí volených orgánů společenství dovolen není. ${ }^{16}$

\section{VADY USNESENÍ SHROMÁŽDĚNÍ}

\subsection{ZÁKLADNÍ OTÁZKY}

Co do základního členění lze rozlišovat dva druhy vad usnesení shromáždění, a to na usnesení neplatná a na usnesení nicotná (nulitní).

13 K rozdílům mezi legislativními termíny „přiměřeně“ a „obdobně“ viz civ. R 17/1992.

14 Rozhodnutí cit. v pozn. 10.

15 Tamtéž.

16 Ve prospěch tohoto výkladu konečně svědčí i analogie s právní úpravou neplatnosti usnesení nejvyššího orgánu kapitálových obchodních společností a družstev. 


\subsubsection{OBECNË}

Neplatné je usnesení shromáždění tehdy, je-li zde rozpor přijatého usnesení shromáždění se zákonem nebo stanovami (§ 1221 odst. 1, § 258 ObčZ).

V daném kontextu vzniká otázka, zda může být usnesení shromáždění neplatné pro rozpor s podzákonným právním předpisem. Nelze $\mathrm{v}$ daném kontextu přehlédnout zjevný rozdíl oproti $\S 191$ odst. $1, \S 428$ odst. $1, \S 663$ odst. 1 a $\S 702$ odst. 1 ZOK, které výslovně určují, že usnesení valné hromady kapitálové obchodní společnosti a členské schůze (shromáždění delegátů) družstva může být neplatné pro rozpor s právními předpisy (tedy nejen pro rozpor se zákonem). Lze nicméně soudit, že jde o problém toliko formální, způsobený toliko terminologickou nekonzistencí práce zákonodárce. Je-li totiž důvodem pro neplatnost usnesení shromáždění i jeho rozpor se stanovami (jež nejsou ani podzákonným právním předpisem), tím spíše je důvodem pro neplatnost usnesení shromáždění jeho rozpor s podzákonným právním předpisem. Opačný výklad, tedy že usnesení shromáždění může být neplatné pro rozpor se zákonem, nikoliv však již s podzákonným právním předpisem, je nelogický, ba př́mo absurdní, a proto je třeba jej důrazně odmítnout.

Závěr je tedy ten, že neplatné je usnesení shromáždění tehdy, je-li zde rozpor přijatého usnesení shromáždění s právními předpisy nebo stanovami. $Z$ toho zřetelně plyne, že usnesení shromáždění musí být v souladu i:

1. s mezinárodními smlouvami, které byly vyhlášeny ve Sbírce zákonů nebo ve Sbírce mezinárodních smluv a k jejichž ratifikaci dal souhlas Parlament ČR (čl. 10 Ústavy ČR),

2. s př́mo použitelnými předpisy EU, které mají podle čl. 288 SFEU přednost před právními předpisy ČR, a

3. s právními předpisy krajů a obcí.

Platná úprava výslovně vyžaduje, aby usnesení shromáždění bylo souladné i se stanovami. Důvod této normativní úpravy je zřejmý. Stanovy jsou zakladatelským právním jednáním společenství konstitutivní povahy, jehož smyslem existence je založení a regulace právních vztahů jednak mezi členy společenství samými, jednak členů společenství ke společenství a společenství ke členům společenství. Vzhledem k tomu je nezbytné je dodržovat, což musí být respektováno i členy společenství.

Jiné než zákonem stanovené důvody neplatnost usnesení shromáždění nevyvolávají. Není tedy s to vyvolat neplatnost usnesení shromáždění porušení jiného, dříve přijatého platného usnesení.

\subsubsection{POVAHA NEPLATNOSTI USNESENÍ SHROMÁŽDĚNÍ}

Podle § 1221 odst. 1 ve spojení s § 259 ObčZ lze podat návrh na vyslovení neplatnosti usnesení shromáždění soudem jen v tam stanovených zákonných lhůtách; jestliže nebyl návrh na vyslovení jeho neplatnosti podán vůbec nebo nebyl úspěšný, lze (ne)platnost usnesení shromáždění přezkoumávat jen tehdy, pokud tak stanoví jiný zákon. 
Usnesení shromáždění je třeba považovat za platné, pokud není pravomocně soudem vyslovena jeho neplatnost (civ. R 59/2017 aj.). Soud z důvodů uvedených v § 260 ObčZ neplatnost usnesení shromáždění nevysloví, pokud to je v zájmu ochrany dobré víry třetích osob, právní jistoty osob nebo ochrany veřejného pořádku.

Z výše uvedeného plyne, že je zákonodárcem koncipována speciální relativní neplatnost usnesení shromáždění, na kterou nelze použít obecnou úpravu relativní neplatnosti právního jednání, což zřetelně plyne z taxativního výčtu osob oprávněných podat návrh na vyslovení neplatnosti usnesení shromáždění a ze zvláštní úpravy lhůt pro podání návrhu v § 259 ObčZ uvedených.

\subsubsection{NICOTNOST USNESENÍ SHROMÁŽDĚNÍ}

Nicotné (nulitní) ${ }^{17}$ je usnesení shromáždění ex definitione tehdy, je-li postiženo vadou tak zásadního významu, že ve skutečnosti o žádné právní jednání nejde. ${ }^{18}$ Obecně vzato, lze za nicotná usnesení pokládat především takové pakty, které přijalo shromáždění, ačkoliv do jeho působnosti vůbec nenáleží. Za nicotné usnesení shromáždění lze považovat takové usnesení, které pro svoji vadu nevyvolává žádné právní účinky.

Nicotné je vždy zejména usnesení shromáždění:

1. o povolání určité osoby do funkce člena voleného orgánu, je-li tato osoba ex lege $\mathrm{k}$ výkonu této funkce nezpůsobilá ( $\$ 155$ odst. 1 věta první ObčZ),

2. které se př́íći dobrým mravům ( $\$ 1221$ odst. $1, \S 245$ věta první ObčZ),

3. o změně stanov, která odporuje kogentním ustanovením zákona ( 1221 odst. 1, $\S 245$ věta první ObčZ). I když bylo rozhodováno výslovně o změnách stanov jako celku (a nebylo tudíž rozhodováno samostatně o jednotlivých změnách) jediným rozhodnutím, je možné se domáhat vyslovení nicotnosti usnesení shromáždění jen ohledně nezákonné části stanov, ${ }^{19}$

4. jestliže jej přijalo shromáždění, ačkoliv do jeho působnosti přijetí tohoto usnesení ani podle zákona ani podle stanov nenáleží (§ 1221 odst. 1 , § 245 věta druhá ObčZ), ${ }^{20}$

5. které ve skutečnosti shromážděním nikdy nebylo přijato, a tedy vůbec neexistuje ( 551 ObčZ),

6. jež je neurčité nebo nesrozumitelné (§ 553 odst. 1 ObčZ). Nejisté je, zda je zde aplikovatelné pravidlo, že byl-li projev vůle mezi stranami dodatečně vyjasněn, nepřihlíží se k jeho vadě a hledí se, jako by tu právní jednání bylo od počátku (§ 553 odst. 2 ObčZ). Z logiky věci lze dovodit kladnou odpověd', nebot' takový výklad konstrukci

17 Označované též jako zdánlivé právní jednání - non negotium.

18 Např́klad ŠVESTKA, J. in: ŠVESTKA, J. - SPÁČIL, J. - ŠKKÁROVÁ, M. - HULMÁK, M. a kol. Občanský zákoník. I, (§ 1-459): komentář. 2. vyd. Praha: C. H. Beck, 2010, s. 316; KNAPP, V. - KNAPPOVÁ, M. - POHL, T. in: ŠVESTKA, J. - DVOŘÁK, J. a kol. Občanské právo hmotné. I. díl. 5. vyd. Praha: Wolters Kluwer ČR, 2010, s. 140; KUBEŠ, V. in: ROUČEK, F. - SEDLÁČEK, J. a kol. Komentár $k$ československému obecnému zákoníku občanskému a občanské právo platné na Slovensku a v Podkarpatské Rusi. Díl 4., (\$\$ 859 až 1089). Praha: V. Linhart, 1936, s. 138; aj.

19 Usnesení Nejvyššího soudu ze dne 27. 4. 2005, sp. zn. 29 Odo 701/2004. Soudní rozhledy. 2006, č. 2, s. 67 a násl.

20 Např́klad rozhodnutí o povolání určité osoby do funkce člena voleného orgánu, není-li orgán společenství přijímající toto rozhodnutí k povolání osoby do funkce vůbec oprávněn. 
zákona nijak neodporuje, ovšem pouze za podmínky, že soud dosud pravomocně nerozhodl o nicotnosti usnesení shromáždění; pak je již vyjasnění jeho obsahu reálně nemožné,

7. prijiaté v působnosti shromáždění osobou, která jako jediný člen společenství vystupuje, ačkoliv jím po právu není. Osoba, která prokáže, že je právoplatným jediným členem společenství, se může domáhat vyslovení jeho nicotnosti v ř́zzení podle $\S 80$ OSŘ, s tím, že bude muset prokázat svůj naléhavý právní zájem na tomto určení, ${ }^{21}$

8. jež shromáždění přijalo ve věcech, které do působnosti shromáždění stanovami svěřit lze, věcně se tak však právem předepsaným způsobem nestalo,

9. které bylo přijato v mezích působnosti shromáždění svěřené jí stanovami, ovšem na základě nicotné nebo neplatné klauzule stanov. Jde zejména o ty př́pady, kdy př́slušná změna stanov nebyla schválena zákonem předepsaným způsobem, ovšem usnesení shromáždění o změně stanov nebylo v zákonné lhůtě napadeno návrhem na vyslovení jeho neplatnosti; v takovém príípadě je marným uplynutím času sice sanována neplatnost usnesení shromáždění, nikoliv však neplatnost změny stanov samých. Je-li tedy př́ślušná (kompetenční) klauzule stanov absolutně neplatná, nemůže jím být založena působnost shromáždění a případné usnesení shromáždění přijaté na základě neplatné kompetenční klauzule stanov je nicotné.

Shromáždění rozhoduje o otázkách, jež do jeho působnosti vyhrazuje zákon. Dále může shromáždění rozhodovat i o otázkách, které do jeho působnosti vyhradí stanovy nebo které si k rozhodování vyhradí svým usnesením. Do působnosti shromáždění však nelze svěřit cokoliv. Tak např. stanoví-li zákon, že statutárním orgánem je předseda nebo výbor, nemůže se shromáždění prohlásit za statutární orgán. Takové usnesení shromáždění je pro zjevný rozpor se zákonem nicotné a nemůže mít právní účinky ani pro vnitřní poměry společenství, ani ve vztahu $\mathrm{k}$ třetím osobám. ${ }^{22}$

Za nicotné lze pokládat i takové usnesení shromáždění, které bylo sice príijato v mezích působnosti shromáždění, avšak bylo v natolik flagrantním rozporu se zákonem, že by jeho realizací hrozil bud'to následek zákonem (ne)přímo zakázaný, nebo by hrozila obzvlášst těžká újma práv (některých) členů společenství nebo třetích osob.

Konečně za nicotná lze pokládat i taková usnesení shromáždění, která byla přijata osobami majícími právní postavení členů společenství, kteří však vědomě sledovali úmysl príijmout, resp. svými hlasy prosadit přijetí usnesení shromáždění, pokud tento projev vůle byl činěn za situace, kdy bylo právními předpisy nebo vykonatelným rozhodnutím orgánu veřejné moci zakázáno takový projev vůle činit. Jestliže společenství respektovalo soudem nařízené předběžné opatření, kterým soud zasedání shromáždění zakázal, a odmítl-li tedy z tohoto důvodu člen statutárního orgánu zasedání shromáždění zahájit, pak zasedání shromáždění nebylo zákonem stanoveným způsobem zahájeno

21 Rozsudek Nejvyššího soudu ze dne 8. 10. 2008, sp. zn. 29 Odo 1639/2006, ASPI JUD142322CZ; usnesení Nejvyššího soudu ze dne 23. 9. 2009, sp. zn. 29 Cdo 3914/2008, ASPI JUD156031CZ; a usnesení Nejvyššího soudu ze dne 16. 6. 2010, sp. zn. 29 Cdo 3247/2009, ASPI JUD183423CZ.

22 Usnesení Nejvyššího soudu ze dne 30. 5. 2000, sp. zn. 32 Cdo 524, 525/2000. Právní rozhledy. 2000, č. 8 , s. 353 a násl.; usnesení Nejvyššího soudu ze dne 1. 6. 2000, sp. zn. 32 Cdo 500/2000. Soudní judikatura. 2000, č. 11, s. 430 a násl.; usnesení Nejvyššího soudu ze dne 27. 4. 2005, sp. zn. 29 Odo 540/2004, ASPI JUD88275CZ; usnesení Nejvyššího soudu ze dne 17. 4. 2007, sp. zn. 29 Odo 757/2005, ASPI JUD $38555 \mathrm{CZ}$; aj. 
a shromáždění zasedalo v rozporu se zákonem, pak nelze usnesení přijatá přítomnými členy společenství na takovém „zasedáni““ považovat za usnesení shromáždění, nebot’ to nebylo způsobilé k jejich přijetí, jelikož o shromáždění vůbec nešlo. ${ }^{23}$

\section{SOUDNÍ ŘÍZENÍ O VYSLOVENÍ NEPLATNOSTI USNESENÍ SHROMÁŽDĚNÍ}

\subsection{ZÁKLADNÍ OTÁZKY}

Soud nesmí zasahovat do vnitřních poměrů právnické osoby nad míru stanovenou zákonem. Možnost prohlásit za neplatné rozhodnutí orgánu právnické osoby z jakýchkoliv důvodů bez omezení by však měla za následek př́lišnou ingerenci orgánů soudní moci do vnitřních záležitostí právnické osoby. I právnická osoba má jistá základní práva a svobody, které jsou ústavněprávně a mezinárodněprávně chráněny; každý zásah do jejích práv a svobod tedy nutně musí mít svůj legitimní, oprávněný účel. Orgány veřejné moci mohou proto zasahovat do vnitřních poměrů právnické osoby pouze potud, pokud si to vyžaduje ochrana základních práv a svobod jejích členů či třetích osob. Jen tak lze docílit stavu, aby tento zásah nevybočil z kautel základních práv a svobod vymezených mezinárodními i vnitrostátními právními předpisy. ${ }^{24}$

Zákon staví usnesení shromáždění pod relevantní soudní kontrolu; umožňuje se jejich soudní přezkum za dodržení přesně stanovených a poměrně formalizovaných podmínek. Smyslem této úpravy je zajistit ochranu práv oprávněných osob před protiprávním postupem těch členů společenství, kteří majíce potřebnou většinu hlasů prosadili prijietí určitého usnesení shromáždění.

Účelem právní úpravy je ochrana práv členů společenství, jakož i třetích osob nabytých bona fides. Právní úprava nutně musí zohledňovat tři základní okruhy zájmů, totiž zájmy členů společenství, zájmy společenství 25 a konečně zájmy třetích osob, z nichž zejména vystupují do popředí zájmy věřitelů. Významným kritériem je faktor časový, nebot' platí, že úměrně s dobou, která uplynula od přijetí vadného usnesení, se přinejmenším komplikuje možnost dosažení nápravy a zvyšuje se nebezpečí zásahu do práv třetích osob nabytých $\mathrm{v}$ dobré viŕe.

Opačný př́stup - tedy nemožnost soudního přezkumu (ne)platnosti usnesení shromáždění - by vedl k porušení práva na spravedlivý proces (čl. 36 odst. 1 LPS), ježto by se osoby dotčené vadným usnesením shromáždění proti němu nemohly reálně nijak bránit.

Otázku (ne)platnosti usnesení shromáždění lze meritorně posoudit pouze v rrízení podle $§ 258$ a násl. ObčZ (§ 1221 odst. 1 ObčZ).

23 Usnesení Nejvyššího soudu ze dne 24. 8. 2010, sp. zn. 29 Cdo 211/2009. Právní rozhledy. 2011, č. 1, s. 27 a násl. (a Soudní judikatura. 2011, č. 3, s. 208 a násl.).

24 Nález Ústavního soudu ze dne 19. 1. 1994, sp. zn. Pl. ÚS 15/93. In: Ústavní soud České republiky. Sbirka nálezů a usnesení. Svazek 1. Praha: C. H. Beck, 1994, s. 23 a násl.

25 Které mohou být a $\mathrm{v}$ řadě ohledů také jsou v př́mé kontrapozici proti zájmům jednotlivých členů společenství nebo některých z nich. 
V ř́izení podle $\S 80$ OSŘ není soudní přezkum (ne)platnosti usnesení shromáždění dovolen, nebot' tomu brání zvláštní zákonná úprava v $§ 258$ a násl. ObčZ. ${ }^{26}$

Právo podat návrh na vyslovení neplatnosti usnesení shromáždění není pouze prostředkem ochrany individuálních práv a právního postavení určitého navrhovatele, nýbrž především nástrojem obecné ochrany zákonnosti ve vnitřních poměrech společenství, resp. souladu těchto vnitřních poměrů $\mathrm{s}$ autonomní úpravou provedenou ve stanovách, a to s ohledem na širší kontext ochrany společenství, resp. osob oprávněných takový návrh podat, jakož i dalších osob, jež mohou být těmito vnitřními poměry dotčeny. ${ }^{27}$

V řízení podle $\S 258$ a násl. ObčZ lze - při splnění omezujících zákonných podmínek - přezkoumat (ne)platnost každého usnesení shromáždění; je bez významu, zda dotčené usnesení shromáždění zakládá skutečnost, která podléhá zápisu do rejstříku společenství, či nikoliv, a zda se předmětný zápis provádí s účinky konstitutivními nebo deklaratorními. ${ }^{28}$

Není možné soudně napadat neplatnost shromáždění. Neplatné může být pouze usnesení shromáždění; pouze to lze napadnout návrhem podaným k soudu na vyslovení jeho neplatnosti. Napadnout lze vždy pouze konkrétní usnesení shromáždění; to nebrání závěru, že přijme-li shromáždění několik různých usnesení, lze napadnout jedno usnesení, některá, popř. i všechna prrijatá usnesení. To, zda a která usnesení budou napadena, záleží výlučně na navrhovateli. Nelze se ovšem dovolávat neplatnosti usnesení, jestliže byl sice určitý návrh usnesení na zasedání shromáždění předložen, avšak nebylo o něm vůbec hlasováno, a proto se tento návrh usnesením shromáždění nestal. ${ }^{29}$

Soud může vyslovit neplatnost usnesení shromáždění pouze tehdy, jsou-li tu splněny určité zákonem stanovené podmínky; není-li splněna byt' jediná z těchto podmínek, není možné vyslovit neplatnost usnesení shromáždění.

Bylo již Ústavním soudem správně judikováno, že: „Základním principem výkladu smluv je priorita výkladu, který nezakládá neplatnost smlouvy, před takovým výkladem, který neplatnost smlouvy zakládá, jsou-li možné oba výklady. Je tak vyjádřen a podporován princip autonomie smluvnich stran, povaha soukromého práva a s tím spojená společenská a hospodářská funkce smlouvy. Není ústavně konformni a je v rozporu s principy právního státu taková praxe, kdy obecné soudy upřednostňují výklad vedoucí k neplatnosti smlouvy před výkladem neplatnost smlouvy nezakládajícím. "30 Tento závěr platí obecně ve vztahu k posuzování (ne)platnosti právních jednání, a je proto plně použitelný i pro oblast posuzování (ne)platnosti usnesení shromáždění v řízení podle $\S 258$ a násl. ObčZ.

26 Usnesení Vrchního soudu v Praze ze dne 19. 3. 2010, sp. zn. 7 Cmo 413/2009, ASPI JUD261928CZ; a rozsudek Nejvyššího soudu ze dne 25. 5. 2015, sp. zn. 29 Cdo 924/2012, ASPI JUD284054CZ.

27 Usnesení Nejvyššího soudu ze dne 27. 5. 2008, sp. zn. 29 Odo 1400/2006, ASPI JUD133636CZ.

${ }^{28}$ Usnesení Nejvyššího soudu ze dne 27. 1. 2009, sp. zn. 29 Cdo 1271/2006. Soudní judikatura. 2008, č. 9, s. 724 a násl.

29 Usnesení Vrchního soudu v Praze ze dne 29. 7. 2009, sp. zn. 7 Cmo 56/2009. Obchodněprávní revue. 2010, č. 8, s. 246 a násl.

30 Nález Ústavního soudu ze dne 14. 4. 2005, sp. zn. I. ÚS 625/03. In: Ústavní soud České republiky. Sbirka nálezů a usnesení. Svazek 37. Praha: C. H. Beck, 2006, s. 157 a násl. 
Nelze přitom zaměňovat řízení podle $§ 258$ a násl. ObčZ s řízením ve věcech rejstř́íku společenství. ${ }^{31}$

Zákon nespecifikuje, s jakým návrhem se má aktivně legitimovaná osoba obrátit na soud. Vzhledem k tomu musí formulace žalobního návrhu (petitu) odpovídat nesouhlasnému stanovisku aktivně legitimované osoby s napadeným usnesením shromáždění. Postupem podle $\S 258$ a násl. ObčZ se aktivně legitimovaná osoba může u soudu domáhat pouze vyslovení neplatnosti usnesení shromáždění. ${ }^{32}$

Ustanovení § 258 a násl. ObčZ se použijí i tehdy, pokud bylo rozhodováno per rollam.

\subsection{POVINNOST DOVOLAT SE NEPLATNOSTI USNESENÍ SHROMÁŽDĚNÍ U ORGÁNƯ SPOLEČENSTVÍ}

Soudní ochrany se oprávněná osoba může dovolávat jen tehdy, pokud se neplatnosti usnesení nelze dovolat u orgánů společenství. Úprava to není (ani na půdě obecného spolkového práva) př́liš jasná.

Úprava vyvolává otázku po smyslu této normy. Zákon zjevně preferuje relativní neplatnost právního jednání oproti neplatnosti absolutní. Není ovšem zřejmé, jaké důsledky tato skutečnost přináší pro oblast práva společenství. Racionální se jeví ten výklad, že oprávněná osoba se má nejprve dovolat neplatnosti usnesení přímo u orgánů společenství (a to jak u shromáždění, tak i u volených orgánů) a teprve tehdy, nebude-li takový postup reálně možný (lhostejno, z jakého důvodu), může podat návrh podle $\S 258$ a násl. ObčZ.

Zákon se zde podle všeho pokouší o prosazení povinnosti oprávněné osoby pokusit se o jakýsi mimosoudní smír ještě před zahájením vlastního soudního řízení, což lze kladně kvitovat. Negativem této úpravy ovšem je povinnost navrhovatele v soudním řízení prokázat, že se pokusil neplatnosti usnesení u orgánů společenství dovolat před podáním návrhu podle $\S 258$ a násl. ObčZ, bude-li to společenstvím v řízení před soudem zpochybněno, což může být dosti obtížné. Krom toho je nejasné, zda vůbec může společenství uznat neplatnost usnesení shromáždění, a pokud ano, jakým způsobem se tak má stát. Odpověd' na otázku patrně zní, že společenství může uznat neplatnost usnesení shromáždění (jinak by předmětná úprava neměla žádný smysl), a to patrně prijietím nového, platného usnesení.

Jak dovolání se neplatnosti, tak podání návrhu k soudu musí navrhovatel stihnout v zákonných lhůtách podle $§ 259$ ObčZ.

\subsection{LHƯTY PRO PODÁNÍ NÁVRHU}

Zásadní podmínkou pro úspěch ve věci samé je včasné podání návrhu na soudní vyslovení neplatnosti usnesení.

31 Usnesení Vrchního soudu v Praze ze dne 20. 5. 2002, sp. zn. 7 Cmo 432/2001. Právní rozhledy. 2002, č. 7 , s. 345 a násl.

32 Rozsudek Nejvyššího soudu ze dne 16. 4. 2014, sp. zn. 26 Cdo 758/2014, ASPI JUD251472CZ. 
Návrh lze podat $\mathrm{v}$ objektivní lhůtě tř́ měsíců ode dne, kdy se navrhovatel dozvěděl o príijatém usnesení, nebo v subjektivní lhůtě tří měsíců ode dne, kdy se navrhovatel mohl dozvědět o přijatém usnesení shromáždění. Je-li navrhovatel na zasedání shromáždění přítomen, je okamžikem, kdy se o přijatém usnesení dozvěděl, okamžik přijetí usnesení; proto lhůta počíná běžet dnem přijetí usnesení, nikoliv až dnem doručení zápisu o zasedání shromáždění. ${ }^{33}$

Návrh je možno podat pouze v objektivní lhůtě jednoho roku ode dne, kdy bylo usnesení shromáždění přijato ( $\$ 259$ ObčZ).

Předpis o objektivní lhůtě se snaží omezit hrozbu právní nejistoty tím, že limituje nepřekročitelným způsobem časový prostor, kdy lze návrh podat. Jde o lhůty prekluzívní; pokud právo nebylo v těchto lhůtách uplatněno, pak zaniká. Obě tyto lhůty mají hmotněprávní povahu; ${ }^{34}$ pro jejich běh je určující $§ 605$ a násl. ObčZ.

Subjektivní i objektivní lhůta musí být bezpodmínečně dodrženy; jejich zmeškání nelze prominout. Po marném uplynutí lhůt již nelze ani přezkoumávat (ne)platnost usnesení shromáždění v řízení podle $\S 258$ a násl. ObčZ, ani nelze v ráádně zahájeném rrízení doplňovat podaný návrh o další důvody neplatnosti.

Nárok na vyslovení neplatnosti usnesení shromáždění samotným zpětvzetím návrhu nezaniká (zpětvzetí samo o sobě nebrání tomu, aby navrhovatel uplatnil obsahově shodný nárok znovu). Nelze však pominout, že právo dovolat se neplatnosti usnesení je časově omezeno zákonnými lhůtami, po jejichž marném uplynutí právo osob vypočtených v § 258 a násl. ObčZ dovolat se vyslovení neplatnosti usnesení shromáždění zaniká. Po uplynutí zákonných lhůt nelze - nebyla-li napadena všechna usnesení shromáždění - ani rozšíriit okruh usnesení, ohledně kterých se navrhovatel vyslovení neplatnosti domáhá. Jestliže tedy navrhovatel vezme svůj návrh na vyslovení neplatnosti usnesení shromáždění (zcela nebo zčásti) zpět a teprve po uplynutí zákonných lhưt se rozhodne uplatnit jej (ve zpětvzatém rozsahu) znovu, je namístě jeho opětovný návrh zamítnout. ${ }^{35}$

To však neplatí bezvýjimečně; de lege lata existují výjimky (k tomu viz výklady dále).

\subsection{AKTIVNÍ LEGITIMACE}

Aktivní legitimaci v ř́zení podle § 258 a násl. ObčZ má každý člen společenství.

Je nejisté, zda má aktivní legitimaci i nečlen, který má na vyslovení neplatnosti usnesení zájem hodný právní ochrany. Jakkoliv budou takové př́pady v praxi patrně raritní, lze soudit, že aktivní legitimaci má i nečlen, např. člen voleného orgánu, který není členem společenství, pokud se brání hrubě vadnému usnesení shromáždění, jímž mu bylo uloženo konat či opomenout něco, co je v hrubém rozporu s jeho zákonnou povinností výkonu funkce s péči rádného hospodáře.

33 Usnesení Nejvyššího soudu ze dne 16. 11. 2016, sp. zn. 26 Cdo 2360/2016. Právní rozhledy. 2017, č. 8 , s. 303.

34 Tamtéž.

35 Usnesení Nejvyššího soudu ze dne 26. 10. 2016, sp. zn. 29 Cdo 1817/2016. Obchodněprávní revue. 2017, č. 2 , s. 50 a násl. 


\section{5 ÚČASTENSTVÍ V ŘÍZENÍ}

Účastníky řízení jsou vždy pouze navrhovatel a společenství (§ 6 Ž̌S $){ }^{36}$

Otázkou je, zda je v řízení přípustné vedlejší účastenství. Obecně vedlejším účastníkem může být ten, kdo má právní zájem na výsledku řízení (§ 93 odst. 1 OSŘ). Vedlejší účastenství je však přípustné toliko v řízení sporném, ${ }^{37}$ což řízení podle $§ \S 85-93$ ZŘS není.

Ř́zení podle §§ 85-93 Ž̌̉ je ovládáno dvěma důležitými zásadami, a to konkrétně zásadou spojení řizení, která vylučuje osoby mající aktivní legitimaci, které návrh nepodaly, z účastenství v řízení, a dále vyšetřovací zásadou, která umožňuje i osobám aktivně legitimovaným, které návrh nepodaly, aby i bez účastenství v řízení sdělovaly soudu relevantní skutečnosti, dokládaly potřebné dokumenty atd. Ochrana zákonnosti může být zajištěna mj. i vstupem státního zastupitelství do řízení podle $\S 8$ odst. 1 písm. i) ZŘS, např. z podnětu jiné osoby aktivně legitimované. Bylo by však obcházením zákona, kdyby osoba aktivně legitimovaná, jež svého oprávnění podat návrh nevyužila, vstoupila do ř́zení jako vedlejší účastník po uplynutí prekluzívních lhůt podle $§ 258$ ObčZ. ${ }^{38}$

\subsection{SPOJENÍ ŘÍZENÍ}

S řízením o vyslovení neplatnosti konkrétního usnesení je spojeno ex lege každé další řízení o neplatnosti téhož usnesení ( 88 odst. 2 ZǨS). Tím je zavedeno zákonné spojení řízení, které vylučuje, aby dva stejné návrhy různých navrhovatelů byly posuzovány odděleně, a tudíž posouzeny jinak. Zákonná úprava však nepředstavuje ani překážku litispendence, ani překážku res iudicata, nebot' nic takového zákon výslovně nestanoví a účastníci řízení jsou v různých řízeních nutně různí.

Druhý a další navrhovatel má tak ex lege postavení samostatného účastníka rrízení (§ 91 odst. 1 OSŘ).

\subsection{DŮKAZNÍ POVINNOST}

Navrhovatel má povinnost tvrdit důvody neplatnosti usnesení shromáždění a předkládat důkazy o tom, není však povinen rozpor napadeného usnesení s právními předpisy nebo stanovami hodnotit po právní stránce, resp. jeho případné hodnocení není pro soud určující. Uvedení důvodů neplatnosti usnesení shromáždění napadeného

36 Usnesení Vrchního soudu v Praze ze dne 1. 3. 2017, sp. zn. 7 Cmo 247/2016. Soudní rozhledy. 2017, č. 4, s. 119 a násl.

37 Shodně např. DRÁPAL, L. in: DRÁPAL, L. - BUREŠ, J. a kol. Občanský soudní řád. I. díl, § 1-200 za: komentár. Praha: C. H. Beck, 2009, s. 605; LAVICKÝ, P. in: DAVID, L. - IŠTVÁNEK, F. - JAVU゚RKOVÁ, N. - KASÍKOVÁ, M. - LAVICKÝ, P. a kol. Občanský soudní ŕád: komentářr. I. díl. Praha: Wolters Kluwer C̆R, 2009, s. 436; a usnesení Vrchního soudu v Praze ze dne 1. 3. 2017, sp. zn. 7 Cmo 247/2016. Soudni rozhledy. 2017, č. 4, s. 119 a násl.

38 Usnesení Vrchního soudu v Praze ze dne 18. 3. 2009, sp. zn. 7 Cmo 428/2008. Obchodněprávní revue. 2011, č. 3, s. 93 a násl. 
návrhem podle $§ 258$ a násl. ObčZ po uplynutí zákonné lhůty pro jeho podání samo o sobě neznamená nemožnost prohlásit usnesení shromáždění za neplatné soudem. ${ }^{39}$

Navrhovatel má v řízení povinnost tvrzení, že napadeným usnesením shromáždění byly porušeny právní předpisy; nemá však povinnost tvrzení, že napadeným usnesením shromáždění byla porušena jeho práva. ${ }^{40}$

\subsection{PRÁVNÍ ÚČINKY ROZHODNUTÍ SOUDU O NEPLATNOSTI USNESENÍ SHROMÁŽDĚNÍ}

Právní úprava stojí na principu, že soud neplatnost usnesení shromáždění neurčuje, nýbrž pouze deklaruje autoritativním způsobem; usnesení je neplatné ex tunc.

Soud rozhodne vždy nejdříve po uplynutí lhůty 3 měsíců od podání návrhu ( $\$ 90$ odst. 2 ZŘS). Smyslem této lhůty je umožnit, aby mohlo být realizováno zákonné spojení ř́zení, což by nebylo věcně proveditelné v situaci, kdy by další účastník návrh na vyslovení neplatnosti usnesení shromáždění podal až po vydání rozhodnutí soudu.

\subsection{DŮVODY, KDY SOUD NEPLATNOST USNESENÍ SHROMÁŽDĚNÍ NEVYSLOVÍ}

Soud neplatnost usnesení shromáždění nevysloví za podmínek a z důvodů stanovených zákonem. Existence těchto důvodů však neznamená, že se tím sanuje př́ípadná nezákonnost usnesení. Soud pouze neplatnost usnesení shromáždění nevysloví, což má za následek jednak formální nenapadnutelnost usnesení shromáždění (res iudicata), jednak všeobecnou závaznost rozhodnutí soudu.

Výčet zákonných důvodů je alternativní, nikoliv kumulativní, tedy i naplnění jediného ze zákonných důvodů postačí $\mathrm{k}$ tomu, aby soud neplatnost usnesení nevyslovil. Je-li naplněn byt' jen jediný zákonný důvod pro vyslovení neplatnosti, je již zbytečné zjišt'ovat, zda tu jsou dány i další důvody pro nevyslovení, či nikoliv. ${ }^{41}$

Soud v řízení o návrhu na vyslovení neplatnosti usnesení shromáždění musí nejprve posoudit soulad napadeného usnesení shromáždění se zákonem a stanovami; teprve poté, kdy dospěje k závěru, že tímto usnesením shromáždění byl porušen zákon či stanovy, zvažuje, zda je namístě vyslovit jeho neplatnost, či zda je naplněn některý z důvodů upravených $v$ § 260 ObčZ, pro které nelze neplatnost usnesení shromáždění vyslovit (civ. R 87/2019).

Je-li zjištěno splnění byt' jen jediného důvodu pro nevyslovení neplatnosti usnesení shromáždění, pak je soud oprávněn a povinen neplatnost usnesení nevyslovit; soud nemá na výběr, zda neplatnost nevysloví, či nikoliv.

Pro primo, soud neplatnost usnesení shromáždění nevysloví, jestliže ( 260 odst. 1 ObčZ):

39 Usnesení Vrchního soudu v Praze ze dne 25. 2. 2008, sp. zn. 7 Cmo 323/2007, ASPI JUD234341CZ.

40 Usnesení Nejvyššího soudu ze dne 23. 5. 2001, sp. zn. 29 Cdo 2337/2000. Právní rozhledy. 2001, č. 6, s. 554 a násl.

${ }^{41}$ Usnesení Nejvyššího soudu ze dne 27. 4. 2005, sp. zn. 29 Odo 445/2004. Soudní judikatura. 2005, č. 6, s. 438 a násl. 
a) usnesením shromáždění došlo k porušení právních předpisů nebo stanov, které nemělo závažné právní následky, a

b) je zde zájem společenství hodný právní ochrany neplatnost usnesení shromáždění nevyslovit (§ 260 odst. 1 ObčZ). Podmínka zájmu společenství hodného právní ochrany je splněna napřr. tehdy, pokud v důsledku přijatého usnesení shromáždění byl zahájen rozsáhlý program rekonstrukce domu, jehož zastavení by závažným způsobem poškodilo členy společenství a ostatní uživatele bytů a nebytových prostorů existujících v tomto domě.

Právo podat návrh podle $\S 258$ a násl. ObčZ není pouze prostředkem ochrany individuálních práv a právního postavení určitého navrhovatele, nýbrž především nástrojem obecné ochrany zákonnosti ve vnitřních poměrech společenství, resp. souladu těchto vnitřních poměrů s autonomní úpravou provedenou ve stanovách, a to s ohledem na širší kontext ochrany společenství, resp. všech osob oprávněných takový návrh podat, jakož i dalších osob, jež mohou být těmito vnitřními poměry dotčeny. V tomto širším kontextu se musí pohybovat nejen soudní přezkum napadených usnesení, nýbrž také úvaha soudu o (ne)aplikaci $§ 260$ odst. 1 ObčZ. Nejde jen o to, jak závažné právní následky mělo porušení právních předpisů a stanov v právní sféře konkrétního navrhovatele, resp. zda se takové důsledky v této sféře vůbec bezprostředně projevily. Neméně podstatné je i posouzení, zda a jaké právní následky takové porušení vyvolalo uvnitř společenství či ve vztahu ke všem osobám, kterých se vnitřní poměry společenství dotýkají, včetně ostatních osob aktivně legitimovaných k podání návrhu podle $\S 258$ ObčZ, byt' by tento návrh v konkrétním př́ípadě nepodaly. ${ }^{42}$

Ustanovení $§ 260$ odst. 1 ObčZ je vyjádřením jedné ze zásad, na kterých spočívá soukromé právo, že totiž důsledky porušení právní povinnosti nesmí být v hrubém nepoměru s dopadem, které toto porušení mělo do právních poměrů oprávněné osoby, ani se závažností takového porušení. ${ }^{43}$

Neplatnost napadených usnesení shromáždění soud nesmí vyslovit v př́ipadě, že porušení práv osob oprávněných domáhat se vyslovení neplatnosti usnesení shromáždění nemá závažné právní následky. ${ }^{44}$ Závěr o tom, že porušení práv nemělo závažné právní následky, lze učinit až poté, co soud rozhodne, že napadeným usnesením shromáždění došlo k porušení právních předpisů nebo stanov dotčeného společenství. ${ }^{45}$

Zájmem společenství, jenž je hoden právní ochrany ve smyslu $§ 260$ odst. 1 ObčZ, je již samotný zájem na stabilitě jeho vnitřních poměrů, chráněný (též) cit. ustanovením. Nejsou-li dány zvláštní okolnosti, jež by odůvodňovaly vyslovení neplatnosti usnesení shromáždění přesto, že porušení právních předpisů nebo stanov nemělo závažné právní následky, bude vždy dán zájem společenství na tom, aby soud neplatnost usnesení nevyslovil.46

Jestliže člen společenství měl informaci o tom, že shromáždění nebylo řádně svoláno, měl při rozhodování o tom, zda se zasedání shromáždění zúčastní, či nikoliv, již

\footnotetext{
42 Usnesení Nejvyššího soudu ze dne 27. 5. 2008, sp. zn. 29 Odo 1400/2006, ASPI JUD133636CZ; a usnesení Nejvyššího soudu ze dne 24. 11. 2009, sp. zn. 29 Cdo 4089/2009, ASPI JUD160447CZ.

43 Usnesení Nejvyššího soudu ze dne 5. 8. 2003, sp. zn. 29 Odo 1013/2002, ASPI JUD27577CZ.

44 Usnesení Nejvyššího soudu ze dne 20. 5. 2010, sp. zn. 29 Cdo 4811/2009, ASPI JUD180973CZ.

45 Usnesení Nejvyššího soudu ze dne 30. 6. 2003, sp. zn. 29 Odo 393/2003, ASPI JUD27562CZ.

46 Usnesení Nejvyššího soudu ze dne 17. 12. 2019, sp. zn. 27 Cdo 787/2018, ASPI JUD441953CZ.
} 
Z pouhé opatrnosti brát v úvahu i to, že soud bude v řízení podle $\S 258$ a násl. ObčZ zvažovat i důsledky pochybení při svolání shromáždění. Skutečnost, že člen společenství chybně vyhodnotil důsledky pochybení při svolání shromáždění, a zasedání se proto nezúčastnil, a tak se sám připravil o možnost uplatnit tímto způsobem svá práva, nemůže být prričítána k tíži společenství, ale důsledky takového hodnocení lze přičítat pouze samému členovi společenství. ${ }^{47}$

Pro secundo, soud neplatnost usnesení shromáždění nevysloví, jestliže by vyslovením neplatnosti usnesení shromáždění došlo $\mathrm{k}$ podstatnému zásahu do práv třetích osob získaných v dobré víře ( $\$ 260$ odst. 2 ObčZ).

Třetí osobou se rozumí osoby stojící vně společenství, tedy typicky věřitelé, dlužníci apod. Naproti tomu třetí osobou nejsou nikdy ani členové společenství ani členové jeho volených orgánů.

Určení, zda již nastal stav, kdy by mohlo dojít k podstatnému zásahu do práv třetích osob získaných v dobré víře, je ponecháno na úvaze soudu. Tento zásah však musí objektivně hrozit, resp. existovat; pouhé subjektivní přesvědčení nebo domněnky nepostačují. Soud zde musí postupovat velmi opatrně.

Dospěje-li soud k závěru, že by prohlášením usnesení shromáždění za neplatné došlo k podstatnému zásahu do práv třetích osob, je jediným omezením, kterým je vázán při rozhodování o tom, zda aplikovat $\S 260$ odst. 2 ObčZ, nedostatek dobré víry na straně třetí osoby, jejímž právům má být poskytnuta ochrana při nabývání chráněného práva. 48

\subsection{ZPĚTVZETÍ (ČÁSTI) NÁVRHU; OCHRANA OSTATNÍCH AKTIVNĚ LEGITIMOVANÝCH OSOB}

Navrhovatel může vzít za řízení zpět návrh na jeho zahájení, a to zčásti nebo zcela (§ 96 odst. 1 OSŘ). Jestliže vzal takto návrh zpět jen jeden z více navrhovatelů, nemá tato skutečnost vliv na další trvání řízení.

Jestliže vzal návrh zpět jediný navrhovatel nebo všichni navrhovatelé, pak:

1. bud’to nejsou splněny podmínky pro zastavení řízení podle $\S 96$ odst. 3 a 4 OSǨ a v řízení se pokračuje, nebo

2. jsou splněny zákonné podmínky pro zastavení řízení podle $\S 96$ odst. 3 a 4 OSŘ, soud však takové řízení nezastaví a bude postupovat podle $\S 91$ Ž̌S.

Zákon se snaží zamezit šikanózním návrhům. Může nastat situace, že navrhovatel vezme zpět svoje podání a jiný návrh v této věci podán není. To by znamenalo, že po uplynutí lhůt nelze již (ne)platnost usnesení shromáždění soudně napadnout. Nebyly v minulosti a ani dnes nejsou v praxi nijak výjimečné případy, že ostatní aktivně legitimované osoby se rozhodnou návrh nepodat, nebot' mají za to, že jeden podaný návrh postačuje, a vyčkávají na soudní rozhodnutí. Pokud je návrh pak vzat zpět, nemohou již ostatní aktivně legitimované osoby vadné usnesení shromáždění soudně napadnout.

47 Usnesení Nejvyššího soudu ze dne 26. 2. 2008, sp. zn. 29 Odo 604/2006, ASPI JUD105574CZ.

48 Usnesení Nejvyššího soudu ze dne 16. 6. 2010, sp. zn. 29 Cdo 3082/2009. Soudní rozhledy. 2012, č. 3, s. 98 a násl. 
Není-li možné pokračovat $\mathrm{v}$ zahájeném řízení proto, že navrhovatel vzal zpět svůj návrh, nebo pro jinou překážku (např. proto, že nebyl zaplacen soudní poplatek), a tuto překážku lze vstupem jiného navrhovatele do řízení a jeho jednáním odstranit, a je-li tu zvláštní zájem těch aktivně legitimovaných osob, které návrh nepodaly, hodný právní ochrany, ${ }^{49}$ soud řízení nezastaví. $V$ takovém případě soud vydá a vyvěsí na úřední desce soudu usnesení, v němž uvede (§ $91 \mathrm{ZŘS}$ ): 50

a) jakého usnesení shromáždění se podaný návrh týká,

b) z jakého důvodu má být řízení zastaveno a jak lze tuto překážku odstranit, a

c) poučení, že řízení bude zastaveno, pokud k podanému návrhu ve lhủtě 3 měsíců ode dne vyvěšení usnesení neprristoupí další navrhovatel a neodstraní v této lhůtě překážku odůvodňující zastavení ř́zení.

Po marném uplynutí lhưty soud řízení zastaví.

\subsection{PRÁVO ČLENA SPOLEČENSTVÍ NA PǨIMĚŘENÉ ZADOSTIUČINĚNÍ}

Člen společenství se může domáhat přiměřeného zadostiučinění za porušení svých základních členských práv závažným způsobem v souvislosti s neplatným usnesením shromáždění, a to i tehdy, pokud člen společenství žádnou újmu neutrpěl.

Závěrem soudu o tom, že napadeným usnesením shromáždění byl porušen zákon či stanovy (a to bez ohledu na to, zda soud vyslovil neplatnost tohoto usnesení či zda návrh zamítl podle $\S 260$ ObčZ), je vázán i soud rozhodující o případném nároku člena společenství na přiměřené zadostiučinění (civ. R 87/2019).

Právo na přiměřené zadostiučinění však členovi společenství vzniká pouze tehdy, nelze-li s ohledem na okolnosti konkrétního př́ípadu uzavřít, že nemajetková újma, způsobená zásahem do základního členského práva, byla sanována již samotným vyslovením neplatnosti usnesení shromáždění. ${ }^{51}$

Toto právo, které může být poskytnuto i v penězích, však musí být uplatněno ve lhůtě (§ 261 odst. 2 ObčZ):

1. určené pro podání návrhu na vyslovení neplatnosti usnesení shromáždění, nebo

2. tří měsíců ode dne, kdy nabylo právní moci rozhodnutí soudu, kterým byl návrh zamítnut z některého důvodu podle $\S 260$ ObčZ.

Jestliže je právo uplatněno později než ve lhůtě podle § 261 odst. 2 ObčZ, pak soud přiměřené zadostiučinění členovi společenství nepřizná, pokud společenství vznese námitku.

Mimo výše uvedený rámec se uplatnění práva na přiměřené zadostiučinění za porušení základních členských práv nepřipouští, nebot' právo na přiměřené zadostiučinění je vázáno na porušení těchto práv v důsledku přijetí usnesení shromáždění, jehož neplatnost soud vyslovil nebo jehož neplatnost soud nevyslovil z důvodů podle $\S 260$ ObčZ.

\footnotetext{
49 Může vyvolávat pochybnosti, co je zájem hodný právní ochrany. Lze však mít za to, že je to např. ochrana základních práv členů společenství, zákaz obmyslného jednání v rozporu s dobrými mravy nebo úmyslné hrubé porušení právních předpisů.

50 Tento postup nemá opodstatnění tehdy, pokud byly podány dva a více návrhů v téže věci.

51 Usnesení Nejvyššího soudu ze dne 29. 4. 2013, sp. zn. 29 Cdo 2838/2011. Právní rozhledy. 2014, č. 2, s. 69 a násl. (a Soudní judikatura. 2014, č. 3, s. 210 a násl.).
} 
Jestliže návrh na vyslovení neplatnosti usnesení shromáždění nebyl vůbec podán nebo bylo ř́zení zastaveno nebo byl návrh zamítnut z jiných důvodů než podle $§ 260$ ObčZ, pak žádné právo na přiměřené zadostiučinění za porušení základních členských práv nelze uplatňovat. ${ }^{52}$

\subsection{POSUZOVÁNÍ (NE)PLATNOSTI USNESENÍ SHROMÁŽDĚNÍ MIMO RÁMEC § 258 A NÁSL. OBČZ}

Není-li vydáno meritorní rozhodnutí soudu v rrízení podle $§ 258$ a násl. ObčZ nebo není-li návrh na vyslovení neplatnosti usnesení shromáždění zamítnut z některého z důvodů uvedených $\mathrm{v} \S 260$ ObčZ, pak může (ne)platnost usnesení shromáždění vždy $\mathrm{v}$ rámci konkrétního řízení přezkoumat jako otázku předběžnou i:

1. civilní soud (§135 odst. 2 OSŘ); rejstř́íkový soud ovšem jen v omezeném rozsahu daném v $\S \S 75-107$ VeřRej,

2. správní soud ( 52 odst. 2 SŘS),

3. správní orgán ( $(40 \mathrm{Sp} \check{R})$, a

4. orgány činné $v$ trestním řízení ( $99 \mathrm{TrR})$.

Dojde-li k posuzování neplatnosti usnesení shromáždění toliko jako otázky předběžné, pak takové posouzení jedním orgánem veřejné moci není závazné pro jiný orgán veřejné moci. Vzhledem $\mathrm{k}$ tomu není vyloučeno, že konkrétní usnesení shromáždění bude jedním orgánem veřejné moci posouzeno jako neplatné, zatímco jiným orgánem veřejné moci jako platné. Ostatně jednotlivé orgány veřejné moci se o tom, že jiné orgány veřejné moci předběžně posoudily konkrétní usnesení shromáždění jako (ne)platné, ani nemusí dozvědět; to je stav sice zjevně nežádoucí, leč de lege lata patrně věcně neřešitelný.

Soudy ovšem tento výklad zjevně nesdílí.

Bylo již judikováno, že jakýkoliv přezkum (ne)platnosti rozhodnutí orgánu soukromoprávní korporace mimo rámec řízení o vyslovení neplatnosti tohoto rozhodnutí není př́ípustný, a to ani v rámci posuzování otázky předběžné. ${ }^{53}$

A dále bylo judikováno, že zákon neumožňuje rejstříkovému soudu přezkoumat (ne)platnost rozhodnutí orgánu soukromoprávní korporace v rejstř́kovém řízení, ve kterém soud rozhoduje o povolení zápisu skutečnosti založené rozhodnutím orgánu soukromoprávní korporace do veřejného rejstř́iku právnických a fyzických osob (civ. R 62/2018). To je ovšem výklad zjevně chybný, nebot' z žádného zákonného ustanovení neplyne, že by zde byla suspendována pravomoc soudu posoudit (ne)platnost usnesení shromáždění jako otázku předběžnou (§ 135 odst. 2 OŠ̌) vždy, není-li tu meritorní rozhodnutí o (ne)platnosti usnesení vydané v ř́zení podle $§ 258$ a násl. ObčZ.

52 Usnesení Vrchního soudu v Praze ze dne 13. 8. 2010, sp. zn. 7 Cmo 336/2009. Soudní rozhledy. 2011, č. 1 , s. 19 a násl.

53 Usnesení Vrchního soudu v Praze ze dne 22. 1. 2015, sp. zn. 7 Cmo 406/2014. Právní rozhledy. 2015, č. 5, s. 188 a násl. 


\section{SOUDNÍ ŘÍZENÍ O VYSLOVENÍ NICOTNOSTI USNESENÍ SHROMÁŽDĚNÍ}

Nicotnosti usnesení shromáždění se lze domáhat v řízení podle $§ 258$ a násl. ObčZ. Jestliže je v řízení podle $\S 258$ a násl. ObčZ vyslovena nicotnost usnesení shromáždění, pak rozhodnutí soudu o vyslovení nicotnosti usnesení má čistě deklaratorní právní účinky. ${ }^{54}$ Se zřetelem $\mathrm{k}$ tomu si lze klást otázku, zda má vůbec smysl domáhat se soudního vyslovení nicotnosti usnesení shromáždění. Odpověd’ je však nepochybně kladná; jedině soudní rozhodnutí může v př́ípadě sporu nebo pochybnosti určit způsobem nepochybným nicotnost usnesení shromáždění, či nikoliv, což poskytuje potřebnou právní jistotu.

Pokud je nicotnost usnesení shromáždění posuzována v řízení podle $§ 258$ a násl. ObčZ, platí zde předpisy o řízení ve věcech neplatnosti usnesení shromáždění s několika výjimkami:

1. návrh lze podat bez jakéhokoliv časového omezení. Rozhodnutí o tom, že je usnesení shromáždění nicotné, lze vydat také tehdy, bylo-li právo na vyslovení neplatnosti usnesení shromáždění uplatněno až po marném uplynutí lhůty k podání návrhu na vyslovení neplatnosti usnesení shromáždění, ${ }^{55}$

2. je-li usnesení nicotné, pak soud nikdy nemůže nevyslovit nicotnost usnesení shromáždění; ustanovení § 260 ObčZ se zde nepoužije,

3. právo domáhat se nicotnosti usnesení shromáždění se ani nepromlčuje ani nezaniká. Vzhledem k tomu není potřebná zvláštní ochrana osob, jež návrh k soudu nepodaly; ustanovení § 91 Ž̌S o zastavení ř́zení se nepoužije, nebot' tento postup zde nemá smysl, jelikož zpětvzetí jediného návrhu nevylučuje, aby (stejná nebo jiná) aktivně legitimovaná osoba návrh kdykoliv (znovu) podala, a

4. soud rozhodne o tom, že usnesení shromáždění je nicotné, i bez návrhu ( $\$ 90$ odst. 1 Ž̌S).

Závěr, že shromáždění přijalo nicotné usnesení, je možné učinit i v jiném soudním řízení než v ř́zení podle $§ 258$ a násl. ObčZ nebo v rejstř́íkovém řízení; soud nebo jiný orgán veřejné moci může vždy tuto otázku posoudit jako otázku předběžnou (civ. R 62/2018).

Osoba, která nemá aktivní legitimaci podle $§ 258$ a násl. ObčZ, se může nicotnosti usnesení shromáždění domáhat v ř́zení podle $\S 80$ OSŘ, musí však prokázat svůj naléhavý právní zájem ve věci samé. Je-li nicotnost usnesení posuzována v ř́izení podle $\S 80$ OŠ̌, použijí se obecné předpisy o civilním soudním ř́zení.

\footnotetext{
54 Usnesení Nejvyššího soudu ze dne 17. 4. 2007, sp. zn. 29 Odo 757/2005. Soudní judikatura. 2007, č. 9, s. 708 a násl.

55 Usnesení Nejvyššího soudu ze dne 20. 3. 2014, sp. zn. 29 Cdo 3656/2012, ASPI JUD249471CZ.
} 


\section{SOUDNÍ ŘÍZENÍ VE VĚCI MERITORNÍHO PŘEZKUMU USNESENÍ SHROMÁŽDĚNÍ}

\subsection{ZÁKLADNÍ OTÁZKY}

Bytové spoluvlastnictví kombinací podílového a reálného spoluvlastnictví; vzhledem k tomu § 1209 odst. 1 a 2 ObčZ - obdobně jako u klasického podílového spoluvlastnictví v § 1139 ObčZ - ve znění po novele provedené zákonem č. 163/2020 Sb. (s účinností od 1. 7. 2020) obsahuje možnost soudní ochrany členů společenství ve věcech správy společných částí.

Soud v řízení podle $§ 1209$ odst. 1 a 2 ObčZ meritorně přezkoumá napadené usnesení shromáždění po věcné stránce. Základní otázkou je, která usnesení shromáždění vlastně soud může přezkoumávat.

Jediným dovoleným předmětem činnosti společenství je správa společných částí podle $\S 1189$ ObčZ ( $\$ 1194$ odst. 1 věta první ObčZ); tomu koresponduje i působnost shromáždění, jež o ničem jiném než o jednotlivých otázkách správy společných částí nemůže vůbec rozhodovat. Jakékoliv usnesení shromáždění se může týkat pouze a výhradně správy společných částí; to platí i o těch usneseních, která se na prvý pohled správou společných částí prímo nezabývají, jako je např. usnesení shromáždění o schválení změny stanov společenství nebo o členství v právnické osobě působící v oblasti bydlení. Jelikož veškerá dovolená činnost společenství je limitována správou společných částí, přičemž správa společných částí je definována dosti široce (,,v̌še, ... co je v zájmu všech vlastníkio jednotek nutné nebo účelné pro rádnou péči o di̊m ... "), je nepochybné, že i např. rozhodování shromáždění o změně stanov společenství nebo o členství v právnické osobě působící v oblasti bydlení je rozhodováním o správě společných částí. Rozhoduje-li tedy soud o záležitosti týkající se správy společných částí, rozhoduje o věcném přezkumu usnesení shromáždění.

Nic nebrání tomu, aby byl podán:

1. pouze návrh podle $\S 258$ a násl. ObčZ,

2. pouze návrh podle $\S 1209$ odst. 1 a 2 ObčZ, nebo

3. návrh podle $\S 258$ a násl. ObčZ a návrh podle $\S 1209$ odst. 1 a 2 ObčZ, přičemž oba návrhy může podat tentýž navrhovatel nebo i různí navrhovatelé.

Jsou-li podány návrhy podle $\S 258$ a násl. ObčZ a podle $\S 1209$ odst. 1 a 2 ObčZ odděleně, pak by soud vždy měl (v zájmu procesní ekonomie) obě řízení spojit ke společnému řízení (§ 112 odst. 1 OSŘ); to platí i tehdy, pokud každý návrh podal jiný navrhovatel.

Ustanovení § 1209 odst. 1 a 2 ObčZ se použijí i tehdy, bylo-li rozhodováno per rollam.

\subsection{MOŽNOSTI ROZHODNUTÍ SOUDU}

Je-li současně s návrhem podle $§ 1209$ odst. 1 a 2 ObčZ podán i návrh podle $\S 258$ a násl. ObčZ, pak soud vždy posoudí v řízení nejprve otázku (ne)platnosti nebo nicotnosti usnesení shromáždění. 
Je-li podán pouze návrh podle $§ 1209$ odst. 1 a 2 ObčZ, pak soud posoudí v řízení otázku (ne)platnosti nebo nicotnosti usnesení shromáždění jako otázku předběžnou (§ 135 odst. 2 OŠ̃).

Nicméně bez zřetele $\mathrm{k}$ tomu, zda bude napadené usnesení shromáždění shledáno jako platné, či nikoliv, nebrání tato skutečnost soudu v tom, aby napadené usnesení shromáždění meritorně přezkoumal a věcně rozhodl; v úvahu připadají následující možnosti rozhodnutí:

1. usnesení shromáždění je shledáno platným, s tím, že není věcný důvod pro zásah soudu do právních poměrů členů společenství,

2. usnesení shromáždění je shledáno platným, s tím, že je věcný důvod pro uspořádání právních poměrů členů společenství soudem,

3. usnesení shromáždění je shledáno neplatným, s tím, že je důvod k nevyslovení jeho neplatnosti a není věcný důvod pro zásah soudu do právních poměrů členů společenství,

4. usnesení shromáždění je shledáno neplatným, s tím, že je důvod pro nevyslovení jeho neplatnosti, avšak je zde věcný důvod pro uspořádání právních poměrů členů společenství soudem,

5. usnesení shromáždění je shledáno neplatným, s tím, že není důvod pro nevyslovení jeho neplatnosti a je věcný důvod pro uspořádání právních poměrů členů společenství soudem,

6. usnesení shromáždění je shledáno nicotným, s tím, že je věcný důvod pro uspořádání právních poměrů členů společenství soudem, nebo

7. usnesení shromáždění je shledáno nicotným, s tím, že není věcný důvod pro zásah soudu do právních poměrů členů společenství.

V př́ípadech výše uvedených ad 2), 4), 5) a 6) tedy soud přistoupí nejen k řešení otázky (ne)platnosti nebo nicotnosti napadeného usnesení shromáždění, nýbrž také $\mathrm{k}$ věcnému řešení situace; zákon má pro tyto príípady dva základní výměry.

Pro primo, soud je povinen uspořádat právní poměry členů společenství podle slušného uvážení. Dikce zákona je nepřesná; zákonodárce opsal in merito totožnou úpravu této otázky u podílového spoluvlastnictví až př́liš bezmyšlenkovitě. Věcně jde o to, že soud zde nahrazuje původní (ne)platné nebo nicotné usnesení shromáždění svým rozhodnutím. Soud je při rozhodování limitován § 1208 ObčZ; nic, co zákon, stanovy nebo atrakční usnesení shromáždění nesvěřují do působnosti shromáždění, nemůže shromáždění projednávat, a tudíž ani soud nemůže v této věci rozhodovat podle $\$ 1209$ odst. 1 a 2 ObčZ.

Pro secundo, soud může zejména rozhodnout, zda se má napadené usnesení shromáždění uskutečnit bez výhrad, s výhradami nebo proti zajištění nebo zda se uskutečnit vůbec nemá.

Výše uvedené konkrétně znamená, že soud ve výroku svého rozhodnutí určí:

1. zda je napadené usnesení shromáždění nicotné, a pokud ano, pak jak soud rozhodne o meritu věci, nebo

2. (a) zda je napadené usnesení shromáždění platné či neplatné, (b) je-li napadené usnesení shromáždění neplatné, zda se vysloví jeho neplatnost, či nikoliv, a (c) je-li napadené usnesení shromáždění platné nebo jeho neplatnost není soudem vyslovena: 
- zda jej soud zruší, s tím, že rozhodne o meritu věci, nebo

- zda jej soud nezruší, avšak rozhodne, zda se má uskutečnit bez výhrad, s výhradami nebo proti zajištění.

Soud, který rozhoduje o meritu věci, je limitován věcnou podstatou projednávané otázky. Řečeno na př́kladu: je-li předmětem napadeného usnesení shromáždění řešení otázky rekonstrukce domovního výtahu, nemůže soud začít řešit otázku odměňování člena voleného orgánu. Soud je limitován petitem návrhu a nemůže jej ignorovat.

Není tedy vyloučeno, aby v těch případech, kdy soud napadené usnesení shromáždění nezruší, rozhodl o podmínkách jeho realizace nebo jej sám modifikoval. Konkrétně bude-li napadeným usnesením shromáždění schválena extrémně předražená rekonstrukce výtahu za 15 milionů Kč, může soud určit, že usnesení shromáždění je platné, ovšem náklady na rekonstrukci výtahu nesmí překročit náklady takové akce v místě a čase obvyklé, tedy 1 milion Kč.

Zatímco v těch př́ípadech, kdy soud určí, že napadené usnesení shromáždění se má uskutečnit bez výhrad nebo s výhradami, je věc zřejmá (jde o to, zda se má napadené usnesení shromáždění realizovat s jednou nebo více podmínkami, nebo naopak bez podmínek), pak je naopak velmi nejasné, jak může soud určit, že napadené usnesení shromáždění se má realizovat proti zajišsění. Analogické využití právní úpravy této otázky $\mathrm{v}$ rámci podílového spoluvlastnictví zde není - vzhledem $\mathrm{k}$ celé řadě otázek správy společné věci, jež jsou odlišné od správy společných částí - dosti dobře možné. Se zřetelem k výše uvedenému lze nicméně soudit, že jde o toliko terminologickou nepřesnost danou mechanickým převzetím normativního textu z právní úpravy podílového spoluvlastnictví. Soud $\mathrm{v}$ těch případech, kdy napadené usnesení shromáždění nezruší, může rozhodnout, že se má uskutečnit bez jakýchkoliv podmínek nebo s jednou či vícero podmínkami stanovenými soudem.

V zásadě stejný bude pak postup soudu v prípadě, kdy bude podán pouze návrh podle $\S 1209$ odst. 1 a 2 ObčZ, aniž by zároveň byl podán návrh podle $\S 258$ a násl. ObčZ. $\mathrm{V}$ takovém př́ípadě soud posoudí otázku neplatnosti nebo nicotnosti napadeného usnesení shromáždění toliko jako otázku předběžnou (§ 135 odst. 2 OSŘ) a v závislosti na výsledku tohoto posouzení pak soud ve výroku svého rozhodnutí určí, zda:

a) je-li inkriminované usnesení shromáždění platné:

- jej soud zruší, s tím, že rozhodne o meritu věci, nebo

- jej soud nezruší, avšak rozhodne, zda se má uskutečnit bez výhrad, s výhradami nebo proti zajištění,

b) je-li inkriminované usnesení shromáždění neplatné nebo nicotné, soud rozhodne o meritu věci, či nikoliv.

\subsection{DŮLEŽITÝ DU゚VOD PRO VĚCNÝ PŘEZKUM USNESENÍ SHROMÁŽDĚNÍ}

Soud věcně přezkoumá usnesení shromáždění podle $§ 1209$ odst. 1 a 2 ObčZ pouze tehdy, je-li pro to důležitý důvod; jde o obligatorní zákonnou podmínku, při jejímž nesplnění soud $\mathrm{k}$ věcnému přezkumu usnesení shromáždění nemůže přistoupit. Co je důležitým důvodem, zákon nestanoví; je proto třeba vyjít z účelu a smyslu zákona. 
Důležitým důvodem se rozumí taková skutečnost, která př́ímo zasahuje bud' do samotného právního postavení členů společenství, nebo do podstaty předmětu jejich bytového spoluvlastnictví z hlediska účelu jeho využití. Přitom nelze přehližet, že do právního postavení členů společenství zasahují (mohou zasahovat) i záležitosti týkající se společenství samotného. Přehlasovaný člen společenství může požádat soud o přezkum přijatého usnesení shromáždění zásadně pouze tehdy, má-li napadené usnesení shromáždění významný dopad do právního postavení, práv či povinností společenství nebo členů společenství. ${ }^{56}$

Podmínka důležitého důvodu je splněna zejména u usnesení shromáždění:

1. o volbě a odvolání členů statutárního orgánu (civ. R 95/2012),

2. které svojí realizací může mít za následek podstatné dotčení hodnoty nebo charakteru celého domu - např.:

a) výměna oken v celém domě (a to i tehdy, má-li být plně hrazena z prostředků krátkodobé nebo dlouhodobé zálohy na opravy a investice), ${ }^{57}$

b) výměna výtahů v domě; podmínka důležitého důvodu je naplněna i u usnesení shromáždění schvalujícího smlouvu o dílo, jež stanoví konkrétní podmínky výměny výtahů, a také schvalující podstatné změny takové smlouvy, ${ }^{58}$ nebo

c) závažná změna důležité společné části. ${ }^{59} \mathrm{~V}$ širším slova smyslu je změnou jakákoliv změna společných částí (včetně vymalování, pořízení nové podlahové krytiny, výměny kování u dveří apod.). Důležitým důvodem však může být jen taková změna, při které dochází ke změně kvality domu a která se zpravidla též nějak dotkne způsobu uživání domu. Opravy, které směřují jen k zachování stávajícího stavu, resp. k tomu, aby se stav nezhoršil (např. i rozsáhlejší oprava střechy směřující $\mathrm{k}$ zamezení zatékání), popř. aby byl odstraněn závadný stav při zachování vnitřního uspořádání domu a velikosti spoluvlastnických podílů na společných částech, takovými změnami zpravidla nejsou, i když může jít o opravy podstatné. 60

Naproti tomu podmínka důležitého důvodu není naplněna u usnesení shromáždění:61

- kterým byl jako zapisovatel shromáždění zvolen jeho předsedající, který je současně předsedou výboru,

- kterým bylo schváleno rozdělení nákladů na celkovou revitalizaci domu, nebot' nejde o usnesení shromáždění, které by př́mo zasahovalo do samotného právního postavení členů společenství nebo do podstaty předmětu jejich vlastnictví; byt' se rozhodnutí dotýká finanční sféry jednotlivých členů společenství, jde jen o obvyklou správu společných částí,

56 Usnesení Nejvyššího soudu ze dne 22. 10. 2008, sp. zn. 28 Cdo 3246/2007, ASPI JUD142669CZ; a rozsudek Nejvyššího soudu ze dne 8. 6. 2016, sp. zn. 26 Cdo 4386/2015, ASPI JUD330351CZ.

57 Rozsudek Nejvyššího soudu ze dne 25. 5. 2011, sp. zn. 22 Cdo 1423/2009. Právní fórum. 2012, č. 5, s. 219 a násl.

58 Usnesení Nejvyššího soudu ze dne 27. 6. 2017, sp. zn. 26 Cdo 2657/2016. Právní rozhledy. 2017, č. 23-24, s. 852 a násl.

59 Otázku umístění strojovny hydraulického osobního výtahu je třeba z hlediska její důležitosti pro provoz výtahu považovat za důležitý důvod. Rozsudek Nejvyššího soudu ze dne 8. 8. 2001, sp. zn. 28 Cdo 1243/2001, ASPI JUD67949CZ.

60 Rozsudek Nejvyššího soudu ze dne 26. 1. 2011, sp. zn. 22 Cdo 1199/2009, ASPI JUD191215CZ.

61 Usnesení Nejvyššího soudu ze dne 19. 3. 2014, sp. zn. 26 Cdo 421/2014, ASPI JUD249538CZ. 
- o schválení rozúčtování ceny služeb, nebot' jde o finanční vyúčtování běžných nákladů na správu společných částí, jejichž výše není zásadní,

- o schválení účetní závěrky a o schválení provize třetí osoby za sjednání úvěrové smlouvy; jde o běžné nakládání s finančními prostředky společenství při správě společných částí,

- o opravě chodníku kolem domu; jde toliko o obvyklou opravu společné části.

\subsection{LHU゚TY PRO PODÁNÍ NÁVRHU}

Zásadní podmínkou pro úspěch ve věci samé je včasné podání návrhu na věcný přezkum usnesení shromáždění.

Návrh lze podat $\mathrm{v}$ objektivní lhůtě tří měsíců ode dne, kdy se navrhovatel dozvěděl o príijatém usnesení shromáždění nebo v subjektivní lhůtě tří měsíců ode dne, kdy se navrhovatel mohl dozvědět o přijatém usnesení shromáždění.

\subsection{AKTIVNÍ LEGITIMACE}

Aktivní legitimaci má každý přehlasovaný člen společenství.

Za přehlasovaného člena společenství je třeba pokládat takového člena společenství, který hlasoval proti návrhu usnesení. Není přitom rozhodné, jak se člen společenství o předloženém návrhu v průběhu diskuse vyjadřoval. ${ }^{62}$ Taktéž není podstatné, zda byl člen společenství osobně prítomen na zasedání shromáždění či se nechal zastoupit, stejně tak jako důvod, pro který nehlasoval proti později zpochybněnému usnesení shromáždění. ${ }^{63}$

Za přehlasovaného člena společenství lze pokládat i takového člena společenství, který se nezúčastnil zasedání shromáždění např. z vážných zdravotních či jiných obdobných důvodů. 64

Za přehlasovaného člena společenství lze pokládat také člena společenství, který se zasedání shromáždění nezúčastnil, protože nebyl v rozporu se zákonem a stanovami na zasedání shromáždění vůbec pozván. ${ }^{65}$

Za situace, kdy člen společenství (řádně pozván na zasedání shromáždění a informován o jeho plánovaném programu) se ze shromáždění vzdálil (nikoli ze zdravotních či jiných vážných důvodů) a nezúčastnil se tedy bez vážných důvodů hlasování o zpochybňovaném usnesení, které bylo přijato, není aktivně věcně legitimován k podání návrhu podle $\S 1209$ odst. 1 a 2 ObčZ, nebot' za této situace ho nelze pokládat za přehlasovaného člena společenství. ${ }^{66}$

Aktivní legitimaci nemá ten člen společenství, který:

1. hlasoval pro napadené usnesení, nebo

2. se sice hlasování nezúčastnil, svým jednáním nebo opomenutím však zřetelně dal najevo, že s přijatým usnesením souhlasí.

62 Rozsudek Nejvyššího soudu ze dne 8. 6. 2016, sp. zn. 26 Cdo 4386/2015, ASPI JUD330351CZ.

63 Rozsudek Nejvyššího soudu ze dne 25. 2. 2015, sp. zn. 29 Cdo 924/2012, ASPI JUD284054CZ.

64 Rozsudek Nejvyššího soudu ze dne 25. 5. 2011, sp. zn. 22 Cdo 1423/2009. Právní fórum. 2012, č. 5, s. 219 a násl.

65 Usnesení Vrchního soudu v Praze ze dne 3. 12. 2009, sp. zn. 7 Cmo 188/2009. Právní rozhledy. 2010, č. 6, s. 223 a násl.

66 Usnesení Nejvyššího soudu ze dne 18. 4. 2018, sp. zn. 26 Cdo 781/2018, ASPI JUD377459CZ. 


\section{6 ÚČASTENSTVÍ V ŘÍZENÍ}

Účastníky ř́zení podle § 1209 odst. 1 a 2 ObčZ jsou vždy pouze žalobce a žalovaný, tj. společenství (§ 90 OSŘ).

\subsection{SPOJENÍ ŘÍZENÍ}

Je-li v téže věci podáno dva nebo více návrhů podle $§ 1209$ odst. 1 a 2 ObčZ různými aktivně legitimovanými osobami, pak by soud měl vždy v zájmu procesní ekonomie všechny tyto návrhy spojit do jediného řízení (§ 112 odst. 1 OSŘ).

\subsection{DOČASNÝ ZÁKAZ JEDNÁNÍ PODLE NAPADENÉHO USNESENÍ SHROMÁŽDĚNÍ}

Navrhovatel může zároveň s vlastním návrhem na věcný přezkum napadeného usnesení shromáždění též navrhnout, aby soud dočasně zakázal společenství podle napadeného usnesení jednat. Meritorně je tato úprava nadbytečná, nebot' nejde o nic jiného než o předběžné opatř̌ení soudu, a to předběžné opatření zdržovací [§ 102 odst. $3, \S 76$ odst. 1 písm. e) OSŘ ]. ${ }^{67}$

Existence této zvláštní úpravy nijak nebrání tomu, aby navrhovatel podal návrh na předběžné opatření zdržovací ještě před vlastním podáním návrhu na věcný přezkum napadeného usnesení shromáždění [§ 76 odst. 1 písm. e) OSŘ]].

\section{SOUDNÍ ŘÍZENÍ VE VĚCI NAHRAZENÍ CHYBĚJÍCÍHO USNESENÍ SHROMÁŽDĚNÍ}

\subsection{ZÁKLADNÍ OTÁZKY}

Při splnění určitých zákonných podmínek připouští zákon v těch případech, kdy shromáždění nebylo usnášeníschopné, nahrazení navrženého, leč nepřijatého usnesení rozhodnutím soudu; úprava je obsažena v $\$ 1209$ odst. 3 ObčZ.

Základní podmínkou řízení je, že návrh př́islušného usnesení byl shromáždění řádně předložen k projednání, avšak shromáždění o předloženém návrhu nerozhodlo pro svoji neusnášeníschopnost. Jestliže však shromáždění předložený návrh neschválilo (nebo dokonce výslovně zamítlo), pak zákonné podmínky pro rozhodnutí soudu o nahrazení nepřijatého usnesení shromáždění splněny nejsou a soud ve věci rozhodovat nemůže.

Návrh podle $\S 1209$ odst. 3 ObčZ může člen společenství podat i tehdy, jestliže se shromáždění v přiměřené době (popř. vưbec) nesešlo, ačkoliv člen společenství o jeho svolání požádal. Podmínka přiměřené doby přitom bude věcí individuálního posouzení reflektujícího zejména zákonnou povinnost svolat shromáždění alespoň jednou ročně a také velikost společenství (civ. R 17/2009).

67 Civ. R 60/2018. 
Zákon neupravuje postup v př́ípadech, kdy:

1. shromáždění projednání předloženého návrhu bez závažného důvodu odložilo na pozdější dobu (typicky do doby svého dalšího zasedání),

2. návrh nebyl řádně předložen shromáždění k projednání postupem stanoveným zákonem a stanovami, nebo

3. návrh byl sice řádně předložen k projednání, avšak shromáždění jej rozhodlo bez závažného důvodu při schvalování programu zasedání z ohlášeného programu vypustit.

Lze nicméně logicky vzato soudit, že i v těchto př́ípadech je postup podle $§ 1209$ odst. 3 ObčZ možný, nebot' jde o principiálně obdobné př́ípady, totiž o nečinnost shromáždění v důsledku neúčasti nebo svévole jednoho nebo více členů společenství.

Zákon tuto otázku sice výslovně neupravuje, nicméně lze soudit, že postup podle $\S 1209$ odst. 3 ObčZ je možný i v těch př́ípadech, kdy byl určitý návrh usnesení předložen k rozhodování per rollam:

a) poté, co bylo svolané shromáždění neusnášeníschopné, nebo

b) opakovaně poté, co při prvém předložení návrhu per rollam většina členů společenství neprojevila jakoukoliv vůli (= hlasování per rollam se nezúčastnila).

Zákon neupravuje žádnou lhůtu pro podání návrhu podle § 1209 odst. 3 ObčZ, lze nicméně soudit, že by návrh měl být podán bez zbytečného odkladu poté, co jsou podmínky zákona splněny. Podání návrhu např. po 5 letech jednak zpravidla již nemá věcný smysl, jednak by jej in concreto bylo možno považovat za rozporný s dobrými mravy, i když jakékoliv paušální závěry nejsou namístě; naopak vždy jsou rozhodné okolnosti konkrétního príípadu.

Soud je při rozhodování limitován § 1208 ObčZ; nic, co zákon, stanovy nebo atrakční usnesení shromáždění nesvěřují do působnosti shromáždění, nemůže shromáždění projednávat, a tudíž ani soud nemůže v této věci rozhodovat podle $\S 1209$ odst. 3 ObčZ.

\subsection{DŮLEŽITÝ DU゚VOD PRO NAHRAZENÍ NEPŘIJATÉHO USNESENÍ SHROMÁŽDĚNÍ ROZHODNUTÍM SOUDU}

Soud nahradí svým rozhodnutím nepřijaté usnesení shromáždění pouze tehdy, je-li pro to důležitý důvod; jde o obligatorní zákonnou podmínku, při jejímž nesplnění soud nahradit nepřijaté usnesení shromáždění svým rozhodnutím nemůže. Co je důležitým důvodem, zákon nestanoví; je proto třeba vyjít z účelu a smyslu zákona.

Lze soudit, že důležitým důvodem pro nahrazení nepřijatého usnesení shromáždění jsou stejné důvody, které jsou důležitým důvodem pro věcné přezkoumání napadeného usnesení soudem v řizení podle $\S 1209$ odst. 1 a 2 ObčZ ( $\mathrm{k}$ tomu viz výklady výše).

\subsection{AKTIVNÍ LEGITIMACE}

Aktivní legitimaci v řízení podle $§ 1209$ odst. 3 ObčZ má každý člen společenství. 


\subsection{SPOJENÍ ŘÍZENÍ}

Je-li v téže věci podáno dva nebo více návrhů podle $\S 1209$ odst. 3 ObčZ různými aktivně legitimovanými osobami, pak by soud měl (v zájmu procesní ekonomie) všechny tyto návrhy spojit do jediného řízení (§ 112 odst. 1 OSŘ).

\section{5 ÚČASTENSTVÍ V ŘÍZENÍ}

Účastníky řízení podle $\S 1209$ odst. 3 ObčZ jsou vždy pouze žalobce a žalovaný, tj. společenství ( $\$ 90$ OSŘ).

\section{SPOLEČNÉ PŘEDPISY}

\subsection{POVAHA ŘÍZENÍ PŘED SOUDEM}

Soudní řízení podle $§ 258$ a násl. ObčZ je nesporným soudním řízením podle $\S \S 85-93$ Ž̌S. Jde o řízení o statusové otázce společenství [ 885 písm. a) Ž̌S]. ${ }^{68}$ Věcně a místně příslušný k řízení je krajský soud vedoucí rejstřík společenství, ve kterém je společenství zapsáno ( $\$ 86$ odst. 1 ZŘS).

Soudní řízení podle $\S 1209$ odst. 1 a 2 ObčZ a podle $\S 1209$ odst. 3 ObčZ je sporným soudním řízením podle $\S 9$ odst. 2 písm. 1) OSŘ. Věcně a místně příslušný $\mathrm{k}$ řízení je krajský soud, v jehož obvodu má společenství své sídlo ( $\$ 85 \mathrm{a}$ ve spojení s $§ 85$ odst. 3 OŠ̆).

Ve všech případech jde vždy o řízení obligatorně návrhové; soud jej nemůže zahájit ex officio.

Navrhovatel nemůže rozšírit okruh napadených usnesení shromáždění po uplynutí lhůt podle $\S 258$ ObčZ nebo podle $\S 1209$ odst. 1 a 2 ObčZ; zúžení okruhu napadených usnesení však př́pustné je.

Bylo judikováno, že je přípustné i po uplynutí lhůt pro podání návrhu k soudu měnit či doplňovat důvody řádně a včas podaného návrhu. ${ }^{69}$ Tento názor je dosti sporný,

68 Třeba souhlasit s kritikou P. Lavického, podle něhož je konstrukce $\S 27$ a $\S 85$ písm. a) Ž̌S důsledkem živelně se vyvíjející právní praxe, která se neblaze projevila i v právní úpravě rízení o některých otázkách právnických osob, a v minulosti k tomuto problému přistupovala značně široce. Statusovou věcí není cokoliv, co souvisí s právnickými osobami. Statusovou povahu zásadně nemají věci týkající se neplatnosti rozhodnutí orgánu právnické osoby. Okolnost, že se o tomto řízení zákon výslovně zmiňuje, ještě neznamená, že jde o statusovou otázku. Viz LAVICKÝ, P. Komentář § 27. In: LAVICKÝ, P. a kol. Řizení nesporné: zákon o zvláštních řizeních soudních, zákon o veřejných rejstř́cích právnických a fyzických osob. Praha: Wolters Kluwer, 2015. Praktický komentáŕ, ASPI KO292_2013CZ. Další autoři pak správně připomínají, že pojem „statusová věc právnické osoby“ užitý v zákonu o zvláštních řízeních soudních je odlišný od pojmu ,statusová otázka“ podle občanského zákoníku. Bohužel v důsledku nekvalitní a nekonzistentní legislativní práce tento obecně přjímaný náhled zákon o zvláštních řízeních soudních nepřejímá a v § 85 písm. a) Ž̌S vytváří zcela vlastní chápání pojmu „statusová věc“ (FELGROVÁ, R. - DEJL, P. Komentáŕ § 85. In: LAVICKÝ, P. a kol. Řizeni nesporné: zákon o zvláštních řizeních soudních, zákon o veřejných rejstř́cích právnických a fyzických osob. Praha: Wolters Kluwer, 2015. Praktický komentár̆, ASPI KO292_2013CZ).

69 Usnesení Nejvyššího soudu ze dne 29. 8. 2001, sp. zn. 29 Odo 71/2001. Právní rozhledy. 2002, č. 1, s. 39 a násl. 
nebot' logicky vzniká otázka, zda se tímto způsobem neotevírají ona ,zadní vrátka“ pro obcházení kogentních lhůt v § 258 ObčZ a $§ 1209$ odst. 1 ObčZ; podle všeho tomu tak skutečně je.

\subsection{SPOLEČNÉ P̌̌EDPISY O AKTIVNÍ LEGITIMACI}

Aktivní legitimaci má člen společenství - výlučný vlastník své jednotky.

Aktivní legitimace je vázána na právní postavení vlastníka jednotky. Žádný ze spoluvlastníků jednotky nemá sám o sobě právní postavení vlastníka jednotky (pouze všichni spoluvlastníci jednotky dohromady), a proto tedy není sám o sobě oprávněn k výkonu práv spojených s jednotkou; $k$ tomu je oprávněn jen správce společné jednotky. Vzhledem k tomu vzniká společná aktivní legitimace všech spoluvlastníků jednotky a také jejich společné účastenství v řízení (§ 91 odst. 2 OSŘ). Tato úprava je věcně velmi nežádoucí, nebot' - docela absurdně - vylučuje samostatný výkon jednoho ze základních práv, totiž práva na soudní ochranu, každým ze spoluvlastníků jednotky, což je z hlediska čl. 36 odst. 1 LPS minimálně diskutabilní, ne-li př́mo protiústavní.

Člen společenství nemusí v řízení prokazovat naléhavý právní zájem na rozhodnutí ve věci; jeho právní zájem je dán vždy z titulu jeho vlastnického práva k jednotce (civ. R 58/2012 aj. ${ }^{70}$ ).

Navrhovatel musí být osobou aktivně legitimovanou v okamžiku podání návrhu.

Dědic vstupuje do členských práv a povinností zesnulého člena společenství v tom „stavu“, v jakém se „nacházely“ ke dni smrti zůstavitele. Podal-li člen společenství návrh, přičemž řízení nebylo ke dni jeho smrti pravomocně skončeno, vstupuje do řízení zahájeného takovým návrhem na jeho místo jako procesní nástupce dědic, jemuž připadla jednotka jeho procesního předchůdce. ${ }^{71}$

V rámci řízení je soud oprávněn zkoumat, zda je osoba, která na zasedání shromáždění hlasovala, vlastníkem jednotky, z titulu jejíhož vlastnictví uplatnila hlasovací právo. $^{72}$

Nabyla-li osoba postavení opravňující k podání návrhu podle $§ 258$ a násl. ObčZ nebo podle $\S 1209$ odst. 1 a 2 ObčZ až po přijetí napadeného usnesení, není aktivně věcně legitimována k podání návrhu do té doby, dokud není na svých právech usnesením shromáždění přímo dotčena. Taková osoba bude aktivně věcně legitimována především tehdy, jestliže skutečnost, že shromáždění přijalo usnesení, jež významně zasahuje do jejích práv, mohla - aniž vynaložila nepřiměřenou námahu - rozpoznat až poté, co nabyla členství ve společenství. ${ }^{73}$

70 Usnesení Vrchního soudu v Praze ze dne 3. 12. 2009, sp. zn. 7 Cmo 188/2009. Právní rozhledy. 2010, č. 6, s. 223 a násl.; usnesení Vrchního soudu v Praze ze dne 19. 3. 2010, sp. zn. 7 Cmo 413/2009. Právní rozhledy. 2010, č. 22, s. 825 a násl.; a rozsudek Nejvyššího soudu ze dne 12. 7. 2016, sp. zn. 26 Cdo 5024/2015, ASPI JUD332211CZ.

71 Usnesení Nejvyššího soudu ze dne 30. 3. 2010, sp. zn. 29 Cdo 1158/2009. Soudní judikatura. 2011, č. 3, s. 156 a násl.

72 Rozsudek Nejvyššího soudu ze dne 6. 9. 2000, sp. zn. 29 Cdo 901/2000. Právní rozhledy. 2000, č. 12, s. 562 a násl.

73 Usnesení Nejvyššího soudu ze dne 24. 6. 2009, sp. zn. 29 Cdo 4354/2008, ASPI JUD153637CZ. 
Ztrátou postavení opravňujícího určitou osobu k podání návrhu ztrácí oprávněná osoba zásadně i svoji aktivní legitimaci (civ. R 72/2001); to neplatí, jestliže tato osoba prokáže, že v době rozhodování soudu trvá její právní zájem na vydání požadovaného rozhodnutí, protože může mít dopad na její právní poměry založené jejím vztahem ke společenství, o (ne)platnost usnesení jeho shromáždění se vede řízení (civ. R 55/2003).

Jestliže může mít usnesení shromáždění dopad na poměry navrhovatele založené jeho vztahem ke společenství i poté, co ztratil postavení zakládající jeho aktivní legitimaci v době podání návrhu, bylo by v rozporu s účelem zákona odepř́t mu aktivní legitimaci v již zahájeném ř́zení. Jeho právní zájem (vyplývající původně z jeho postavení ve společenství) na rozhodnutí o případné (ne)platnosti usnesení shromáždění ztrátou postavení opravňující ho k podání návrhu nepominul. Proto musí soud vždy zkoumat, zda v době vydání rozhodnutí ve věci samé trvá právní zájem navrhovatele na jeho vydání, a tedy i jeho aktivní legitimace. Tento právní zájem na vyslovení neplatnosti usnesení shromáždění je tř̌eba pečlivě odlišit od naléhavého právního zájmu podle $\S 80$ OŠ̌, o které nelze v řízení podle $\S 258$ a násl. ObčZ aktivní legitimaci opírat. ${ }^{74}$

Pro posouzení aktivní legitimace navrhovatele je rozhodující stav v okamžiku vydání rozhodnutí soudu (civ. R 25/2003).

Tato úprava má kogentní povahu, z čehož plyne, že nikdo jiný návrh podle $§ 258$ a násl. ObčZ, podle $\S 1209$ odst. 1 a 2 ObčZ a podle $\S 1209$ odst. 3 ObčZ podat nemůže.

\subsection{PASIVNÍ LEGITIMACE}

Pasivní legitimaci v řízení podle $§ 258$ a násl. ObčZ, v ř́ízení podle § 1209 odst. 1 a 2 ObčZ nebo v řízení podle $\S 1209$ odst. 3 ObčZ má vždy dotčené společenství. ${ }^{75}$

\subsection{PŘERUŠENÍ ŘÍZENÍ V DŮSLEDKU PROHLÁŠENÍ KONKURSU NA MAJETEK SPOLEČENSTVÍ}

Prohlášením konkursu na majetek společenství, jež je v postavení odpůrce v řízení podle $\S 258$ a násl. ObčZ, v řízení podle $\S 1209$ odst. 1 a 2 ObčZ nebo v řízení podle $\S 1209$ odst. 3 ObčZ, se ex lege přerušuje mj. i toto řízení, pokud jde o ř́zení o právech a povinnostech, které se týkají majetkové podstaty nebo které mají být uspokojeny z majetkové podstaty, je-li jejich účastníkem společenství (§ 263 odst. 1 InsZ).

Nepřerušuje se každé řízení, nýbrž pouze takové, které se týká majetkových plnění majících dopad na majetkovou podstatu. Konkrétně se přerušuje např. řízení o vyslovení neplatnosti usnesení shromáždění, kterým bylo rozhodnuto o přiznání odměn

${ }^{74}$ Usnesení Nejvyššího soudu ze dne 28. 4. 2008, sp. zn. 29 Cdo 763/2007, ASPI JUD133359CZ.

75 Shodně FIALA, J. Pasivní věcná legitimace společenství vlastníků jednotek. Právní fórum. 2005, č. 4, s. 133; nález Ústavního soudu ze dne 8. 3. 2005, sp. zn. I. ÚS 646/04. In: Ústavní soud České republiky. Sbirka nálezů a usnesení. Svazek 36. Praha: C. H. Beck, 2006, s. 525 a násl.; a rozsudek Nejvyššího soudu ze dne 23. 8. 2007, sp. zn. 28 Cdo 2618/2007, ASPI JUD103708CZ. 
členům voleného orgánu ${ }^{76}$ nebo kterým bylo schváleno určité majetkoprávní jednání společenství.

\subsection{ZÁVAZNOST PRAVOMOCNÉHO VÝROKU ROZHODNUTÍ SOUDU}

Výrok pravomocného rozhodnutí soudu v řízení podle $§ 258$ a násl. ObčZ je výrokem o statusové otázce právnické osoby, a proto je závazný pro každého ( $\$ 27$ ZŘS).

Vzniká otázka, zda tato úprava dopadá i na prrípady, kdy bude podaný návrh zamítnut např. jen pro procesní pochybení navrhovatele. Pokud by se vyšlo z toho, že i výrok soudu o zamítnutí nebo odmítnutí návrhu je zavazující, pak by soud nebo jiný orgán veřejné moci nemohl v jiném řízení (ne)platnost usnesení shromáždění posoudit jako otázku předběžnou. Takový výklad zákona by se nutně rozcházel s jeho účelem i smyslem. Nelze proto jinak než vykládat zákon tak, že je zde vázanost toliko meritorním výrokem rozhodnutí soudu (např. že usnesení shromáždění je neplatné, nebo že se jeho neplatnost nevyslovuje nebo že se návrh zamítá pro věcnou neopodstatněnost). Pokud však soud např. zastaví řízení proto, že návrh nesplňuje zákonem stanovené požadavky, pak tím není meritorně rozhodnuto ve věci samé a takový soudní verdikt nelze považovat za závazný ve smyslu $§ 27$ Ž̌S.

Výrok pravomocného rozhodnutí soudu v ř́zení podle $\S 1209$ odst. 1 a 2 ObčZ a v rrízení podle $\S 1209$ odst. 3 ObčZ je závazný pro účastníky řízení a orgány veřejné moci (§ 159a OSŘ).

Vzhledem k tomu může být předmětem pochybnosti, je-li takové soudní rozhodnutí závazné i pro ty členy společenství, kteří nebyli účastníky soudního řízení. Odpověd' je však nutně kladná. Usnesení shromáždění je usnesením nejvyššího orgánu společenství, jehož členy jsou všichni členové společenství bez výjimky a které zavazuje každého člena společenství, at' již s ním souhlasí, či nikoliv; to, zda usnesení shromáždění bylo přijato hlasováním jakožto projevem vůle členů společenství nebo rozhodnutím soudu (jenž změnil původní usnesení nebo chybějící usnesení nahradil), je nerozhodné.

\section{ZÁVĚR}

závěry.

Pokusíme-li se shrnout výše řečené, lze formulovat následující všeobecné

Zákonodárce racionálně zareagoval na značné obtíže praxe a zásadním způsobem rozšíril soudní přezkoumatelnost usnesení shromáždění společenství. Počínaje 1. 7. 2020 se lze dovolat nejen neplatnosti usnesení nebo nahrazení usnesení nepřijatého pro neusnášeníschopnost shromáždění, nýbrž i věcného přezkumu platného usnesení shromáždění; tím bylo odstraněno nedůvodné znevýhodnění členů společenství oproti podílovým spoluvlastníkům.

76 Usnesení Nejvyššího soudu ze dne 11. 12. 2001, sp. zn. 29 Cdo 2072/2001, ASPI JUD68447CZ. 
Je značně nejisté, zda lze soudně přezkoumat toliko usnesení shromáždění nebo i rozhodnutí volených orgánů společenství. $Z$ důvodů dř́ve uvedených lze soudit, že je možný toliko soudní přezkum usnesení shromáždění.

V posledních letech se stalo v České republice již téměř notorietou zákonodárce kritizovat za tu či onu legislativní úpravu. Je nepř́iliš veselým zjištěním, že ani tentokrát si zákonodárce za svůj výkon př́lišs chvály nezaslouží. Zákonná úprava je složitá a značně nejasná a již dnes lze s jistotou prorokovat, že bude v praxi činit nemalé obtíže. Bohužel zákonodárce opět zapomněl na starou právnickou parolu, totiž že ,zákony mají být psány pro lidi, a ne proto, aby si na nich právníci zkoušeli svi̊j juristický ostrovtip “. Bohužel není důvodu očekávat, že by se to mělo v blízké budoucnosti změnit k lepšímu.

doc. JUDr. Tomáš Dvořák, PhD.

Právnická fakulta Západočeské univerzity v Plzni

thomas@kop.zcu.cz 